Prepared in cooperation with the United States Army Corps of Engineers, Vicksburg District

\title{
Occurrence and Transport of Nitrogen in the Big Sunflower River, Northwestern Mississippi, October 2009-June 2011
}

Scientific Investigations Report 2014-5107

U.S. Department of the Interior U.S. Geological Survey. 
Cover. (Front) Big Sunflower River at Sunflower, MS. (Back, top photo) Big Sunflower River at Clarksdale, MS. (Back, bottom photo) Big Sunflower near Anguilla, MS. Photographs by Jeannie R.B. Barlow. 


\section{Occurrence and Transport of Nitrogen in the Big Sunflower River, Northwestern Mississippi, October 2009-June 2011}

By Jeannie R.B. Barlow and Richard H. Coupe

Prepared in cooperation with the United States Army Corps of Engineers, Vicksburg District

Scientific Investigations Report 2014-5107 


\title{
U.S. Department of the Interior SALLY JEWELL, Secretary
}

\section{U.S. Geological Survey Suzette M. Kimball, Acting Director}

\author{
U.S. Geological Survey, Reston, Virginia: 2014
}

For more information on the USGS - the Federal source for science about the Earth, its natural and living resources, natural hazards, and the environment, visit http://www.usgs.gov or call 1-888-ASK-USGS.

For an overview of USGS information products, including maps, imagery, and publications, visit http://www.usgs.gov/pubprod

To order this and other USGS information products, visit http://store.usgs.gov

Any use of trade, firm, or product names is for descriptive purposes only and does not imply endorsement by the U.S. Government.

Although this information product, for the most part, is in the public domain, it also may contain copyrighted materials as noted in the text. Permission to reproduce copyrighted items must be secured from the copyright owner.

Suggested citation:

Barlow, J.R.B., and Coupe, R.H., 2014, Occurrence and transport of nitrogen in the Big Sunflower River, northwestern Mississippi, October 2009-June 2011: U.S. Geological Survey Scientific Investigations Report 2014-5107, 29 p., http://dx.doi.org/10.3133/sir20145107.

ISSN 2328-0328 (online) 


\section{Contents}

Abstract
Introduction
Purpose and Scope
Description of Study Area
Hydrologic Setting

\section{Figures}

1. Map showing location of study area and sampling locations with map identification number and extents of the Yazoo River and Big Sunflower River Basins and the Mississippi River Valley alluvial aquifer.

2. Graph showing drainage area along the Big Sunflower River and median streamflow for each of the four gaging stations throughout the study period...

3. Pie chart showing nitrogen load by source in the Big Sunflower River Basin and percentages of total load. 
4. Graphs showing total crop area, relative percentage of dominant crop types within the Big Sunflower River Basin, and average recommended amount of nitrogen applied per drainage area by crop.

5. Box plots showing the distribution of streamflow at the time samples were collected in comparison to the distribution of streamflow throughout the study period

6. Graphs showing streamflow and concentrations of total nitrogen, organic nitrogen, ammonia, and nitrate plus nitrate for each of the four regularly sampled streamgage sites on the Big Sunflower River

7. Box plots showing the distribution of concentrations of total nitrogen, organic nitrogen, ammonia, and nitrate plus nitrite and the ratio of each form of nitrogen to total nitrogen at each of the regularly sampled streamgage sites.

8. Box plots showing the seasonal distribution of concentrations of total nitrogen, organic nitrogen, ammonia, and nitrate plus nitrite and the ratio of each form of nitrogen to total nitrogen in samples collected from the Big Sunflower River between October 1, 2009, and June 30, 2011

9. Box plots showing the seasonal distribution of streamflow, specific conductance, water temperature, dissolved oxygen, and turbidity in the Big Sunflower River between October 1, 2009, and June 30, 2011

10 Graph showing streamflow along the Big Sunflower River and the primary tributaries to the Big Sunflower River during each Lagrangian sampling event 16

11 Graphs showing the flux of nitrogen and concentration of nitrogen as a function of distance from Clarksdale during the April 2010 Lagrangian sampling event.

12 Graphs showing the flux of nitrogen and chloride and concentration of nitrogen and chloride as a function of distance from Clarksdale during the May 2010 Lagrangian sampling event.

13 Graphs showing the flux of nitrogen and chloride and concentration of nitrogen and chloride as a function of distance from Clarksdale during the June 2010 Lagrangian sampling event.

14 Graphs showing the flux of nitrogen and chloride and concentration of nitrogen and chloride as a function of distance from Clarksdale during the August 2010 Lagrangian sampling event

15 Graphs showing the flux of nitrogen and chloride and concentration of nitrogen and chloride as a function of distance from Clarksdale during the May 2011 Lagrangian sampling event

16 Graphs showing the instantaneous flux of total nitrogen relative to the instantaneous flux of chloride, drainage area, and predicted instantaneous total nitrogen fluxes from SPARROW models

17 Graph showing the variability in concentrations of dissolved oxygen with depth and the depth composite concentrations of nitrate plus nitrite at the Little Diversion Canal near Redwing, Miss., site before and after the closure of the Steele Bayou drainage control structure

\section{Tables}

1. Summary of sites sampled within the Big Sunflower River Basin.

2. Summary statistics for selected physical properties measured at the time of sample collection and correlation coefficients between each physical property and concentration of nitrogen 


\section{Conversion Factors}

Inch/Pound to SI

\begin{tabular}{|c|c|c|}
\hline Multiply & By & To obtain \\
\hline \multicolumn{3}{|c|}{ Length } \\
\hline inch (in.) & 2.54 & centimeter $(\mathrm{cm})$ \\
\hline inch (in.) & 25.4 & millimeter $(\mathrm{mm})$ \\
\hline foot $(\mathrm{ft})$ & 0.3048 & meter $(\mathrm{m})$ \\
\hline mile (mi) & 1.609 & kilometer $(\mathrm{km})$ \\
\hline \multicolumn{3}{|c|}{ Area } \\
\hline acre & 4,047 & square meter $\left(\mathrm{m}^{2}\right)$ \\
\hline acre & 0.4047 & hectare (ha) \\
\hline acre & 0.4047 & square hectometer $\left(\mathrm{hm}^{2}\right)$ \\
\hline acre & 0.004047 & square kilometer $\left(\mathrm{km}^{2}\right)$ \\
\hline square mile $\left(\mathrm{mi}^{2}\right)$ & 259.0 & hectare (ha) \\
\hline square mile $\left(\mathrm{mi}^{2}\right)$ & 2.590 & square kilometer $\left(\mathrm{km}^{2}\right)$ \\
\hline \multicolumn{3}{|c|}{ Flow rate } \\
\hline cubic foot per second $\left(\mathrm{ft}^{3} / \mathrm{s}\right)$ & 0.02832 & cubic meter per second $\left(\mathrm{m}^{3} / \mathrm{s}\right)$ \\
\hline \multicolumn{3}{|c|}{ Mass } \\
\hline pound, avoirdupois (lb) & 0.4536 & kilogram (kg) \\
\hline
\end{tabular}

Temperature in degrees Celsius $\left({ }^{\circ} \mathrm{C}\right)$ may be converted to degrees Fahrenheit $\left({ }^{\circ} \mathrm{F}\right)$ as follows:

${ }^{\circ} \mathrm{F}=\left(1.8 x^{\circ} \mathrm{C}\right)+32$

Vertical coordinate information is referenced to the National Geodetic Vertical Datum of 1929 (NGVD 29)

Horizontal coordinate information is referenced to the North American Datum of 1983 (NAD 83).

Specific conductance is given in microsiemens per centimeter at 25 degrees Celsius $(\mu \mathrm{S} / \mathrm{cm}$ at $\left.25^{\circ} \mathrm{C}\right)$.

Concentrations of chemical constituents in water are given in milligrams per liter $(\mathrm{mg} / \mathrm{L})$

Altitude, as used in this report, refers to distance above the vertical datum.

Water-year definition: Water year is the 12-month period from October 1 through September 30 of the following calendar year. The water year is designated by the calendar year in which it ends. For example, water year 2010 is the period from October 1, 2009, through September 30, 2010. 


\begin{tabular}{|c|c|}
\hline MDEO & Mississippi Department of Environmental Quality \\
\hline$\mu \mathrm{m}$ & micrometer \\
\hline$\mu \mathrm{mol} \mathrm{N} \mathrm{m} \mathrm{m}^{-2} \mathrm{~h}^{-1}$ & micromoles nitrogen per square meter per hour \\
\hline NWQL & National Water-Quality Laboratory \\
\hline $\mathrm{R}^{2}$ & coefficient of determination \\
\hline SPARROW & Spatially Referenced Regressions on Watershed attributes (model) \\
\hline USGS & U.S. Geological Survey \\
\hline
\end{tabular}




\title{
Occurrence and Transport of Nitrogen in the Big Sunflower River, Northwestern Mississippi, October 2009-June 2011
}

\author{
By Jeannie R.B. Barlow and Richard H. Coupe
}

\section{Abstract}

The Big Sunflower River Basin, located within the Yazoo River Basin, is subject to large annual inputs of nitrogen from agriculture, atmospheric deposition, and point sources. Understanding how nutrients are transported in, and downstream from, the Big Sunflower River is key to quantifying their eutrophying effects on the Gulf. Recent results from two Spatially Referenced Regressions on Watershed attributes (SPARROW models), which include the Big Sunflower River, indicate minimal losses of nitrogen in stream reaches typical of the main channels of major river systems. If SPARROW assumptions of relatively conservative transport of nitrogen are correct and surface-water losses through the bed of the Big Sunflower River are negligible, then options for managing nutrient loads to the Gulf of Mexico may be limited. Simply put, if every pound of nitrogen entering the Delta is eventually delivered to the Gulf, then the only effective nutrient management option in the Delta is to reduce inputs. If, on the other hand, it can be shown that processes within river channels of the Mississippi Delta act to reduce the mass of nitrogen in transport, other hydrologic approaches may be designed to further limit nitrogen transport. Direct validation of existing SPARROW models for the Delta is a first step in assessing the assumptions underlying those models.

In order to characterize spatial and temporal variability of nitrogen in the Big Sunflower River Basin, water samples were collected at four U.S. Geological Survey gaging stations located on the Big Sunflower River between October 1, 2009, and June 30,2011. Nitrogen concentrations were generally highest at each site during the spring of the 2010 water year and the fall and winter of the 2011 water year. Additionally, the dominant form of nitrogen varied between sites. For example, in samples collected from the most upstream site (Clarksdale), the concentration of organic nitrogen was generally higher than the concentrations of ammonia and nitrate plus nitrite; conversely, at sites farther downstream (that is, at Sunflower and Anguilla), nitrate plus nitrite concentrations were generally higher than concentrations of organic nitrogen and ammonia.

In addition to the routinely collected samples, water samples from the Big Sunflower River Basin were collected using a Lagrangian sampling scheme, which attempts to follow a single mass of water through time in order to determine how it changes through processing or other pathways as the water moves downstream. Lagrangian sampling was conducted five times during the study period: (1) April 8-21, 2010, (2) May 12-June 3, 2010, (3) June 15-July 1, 2010, (4) August 23-30, 2010, and (5) May 16-20, 2011. Streamflow conditions were variable for each sampling event because of input from local precipitation and irrigation return flow, and streamflow losses through the streambed. Streamflow and total nitrogen flux increased with drainage area, and the dominant form of nitrogen varied with drainage area size and temporally across sampling events.

Results from each method indicate relatively conservative transport of nitrogen within the 160 miles between Clarksdale and Anguilla, providing further validation of the SPARROW models. Furthermore, these results suggest relatively conservative transport of nitrogen from the Big Sunflower River to the Gulf of Mexico and, therefore, imply a fairly close association of nutrient application and export from the Big Sunflower River Basin to the Mississippi River. However, within the Big Sunflower River Basin, two potential nitrogen sinks were identified and include the transport and potential transformation of nitrogen through the streambed and the sequestration and potential transformation of nitrogen above the drainage control structures downstream of Anguilla. By coupling these potential loss mechanisms with nitrogen transport dynamics, it may be possible to further reduce the amount of nitrogen leaving the Big Sunflower River Basin and ultimately arriving at the Gulf of Mexico. 


\section{Introduction}

Nitrogen and phosphorus in the Mississippi River contribute to increases in eutrophication and an expanding hypoxic zone in the northern Gulf of Mexico (Rabalais and others, 1996; Goolsby and Battaglin, 2001; Rabalais and Turner, 2001). In recent publications, the State of Mississippi was included among nine states in the central United States believed to be major contributors of nutrients to the Gulf (Alexander and others, 2008; Robertson and others, 2009). In northwestern Mississippi, the fertile agricultural area commonly referred to as the Delta is drained by the Yazoo River, which joins the Mississippi River, just above Vicksburg. The magnitude of discharges from the Yazoo River Basin and the close proximity of the river's outlet to the Gulf of Mexico has led to general concern that nitrogen entering the Mississippi River from the Yazoo River Basin may be transported with minimal loss to the Gulf (Alexander and others, 2008; Coupe and others, 2013).

The Big Sunflower River Basin, located within the Yazoo River Basin (fig. 1), is subject to large annual inputs of nitrogen from agriculture, atmospheric deposition, and point sources. Understanding how nutrients are transported in, and downstream from, the Big Sunflower River is key to quantifying their eutrophying effects on the Gulf. Recent results from two Spatially Referenced Regressions on Watershed attributes (SPARROW models) indicate minimal losses of nitrogen in stream reaches typical of the main channels of major river systems (Alexander and others, 2008; Robertson and others, 2009; Rebich and others, 2011). These models included the Big Sunflower and Yazoo Rivers and inferences concerning larger rivers would seem to apply to the range of flows observed in the Big Sunflower River. There is, however, some possibility that this characterization underestimates nitrogen loss for the Big Sunflower River because the calibration of loss coefficients in SPARROW included observations from streams in more northern parts of the Mississippi River Basin where relatively cooler water temperatures and faster stream velocities act to slow in-channel reaction rates and shorten reaction periods. In addition, losses of nitrogen from the Big Sunflower River may be somewhat enhanced by processes of groundwater exchange driven by a large cone of depression in the alluvial aquifer beneath the streambed of central reaches of the river (Barlow and Clark, 2011).

If current SPARROW calibrations apply and surfacewater losses through the bed of the Big Sunflower River can be discounted, then options for managing nutrient loads to the Gulf of Mexico may be limited. Simply put, if every pound of nitrogen entering the Delta is eventually delivered to the Gulf, then the only effective nutrient management option in the Delta is to reduce inputs. If, on the other hand, it can be shown that processes within river channels of the Mississippi Delta act to reduce the mass of nitrogen in transport, other hydrologic approaches may be designed to further limit nitrogen transport. Direct validation of existing SPARROW models for the Delta is a first step in assessing the assumptions underlying those models.

The U.S. Geological Survey (USGS), in cooperation with the U.S. Army Corps of Engineers, initiated a study in 2010 to characterize the occurrence and transport of nitrogen in the Big Sunflower River Basin. The specific objective was to validate the results from the two SPARROW models for the Big Sunflower River Basin while providing further information about nitrogen transport within the Big Sunflower River Basin, which contributes much of the water discharging from the Yazoo River Basin to the Mississippi River. This investigation supports the USGS strategic science directions in helping to understand ecosystems and predicting ecosystem change, in providing information and forecasts of likely outcomes for water quality and aquatic ecosystem health, and by providing data and information that can be used to protect and enhance water resources.

\section{Purpose and Scope}

The purpose of this report is to describe the occurrence and transport of nitrogen in the Big Sunflower River Basin. The study area includes part of the Big Sunflower River Basin between Clarksdale, Mississippi (Miss.) and Anguilla, Miss. within the Yazoo River Basin in northwestern Mississippi. Water samples and other pertinent data were collected between October 1, 2009, and June 30, 2011. Spatial and temporal variability of nitrogen in the Big Sunflower River Basin were assessed by analyzing water-quality data from routinely collected water samples from four sites located on the Big Sunflower River. Transport mechanisms of nitrogen once it enters the main channel of the river were examined using routine and Lagrangian samples for water-quality at 16 sites located on the Big Sunflower River and its major tributaries. The hypothesis proposed and tested herein is that, counter to the assumptions within the SPARROW models, transport of nitrogen within the Big Sunflower River is not conservative due to instream loss mechanisms, which result in a net loss of nitrogen. For the purpose of this study, net loss of nitrogen is defined as a measurable decrease in the mass or flux of total nitrogen relative to chloride flux (a conservative constituent), drainage area, and (or) predicted total nitrogen fluxes from two previously published SPARROW models that assume relatively conservative transport of nitrogen within the main channel of the Big Sunflower River. Therefore, this hypothesis was tested by comparing the measured flux of nitrogen from the Lagrangian samples to the flux of chloride, drainage area, and predicted total nitrogen fluxes from the two SPARROW models.

\section{Description of Study Area}

Once a floodplain to the Mississippi River covered with bottomland hardwoods, marshes, and wetlands, the Big Sunflower River Basin has been protected by levees and substantially modified to produce an agricultural region that is highly 


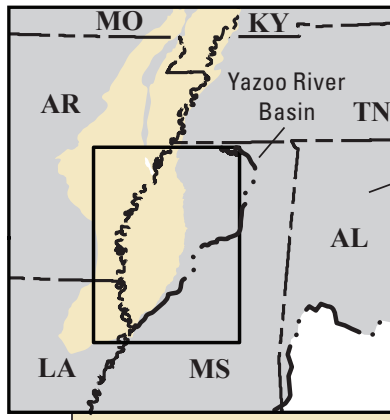

Location of study area, Mississippi River Valley alluvial aquifer, Yazoo River Basin, and

Mississippi River Basin in

Arkansas, Louisiana, and Mississippi
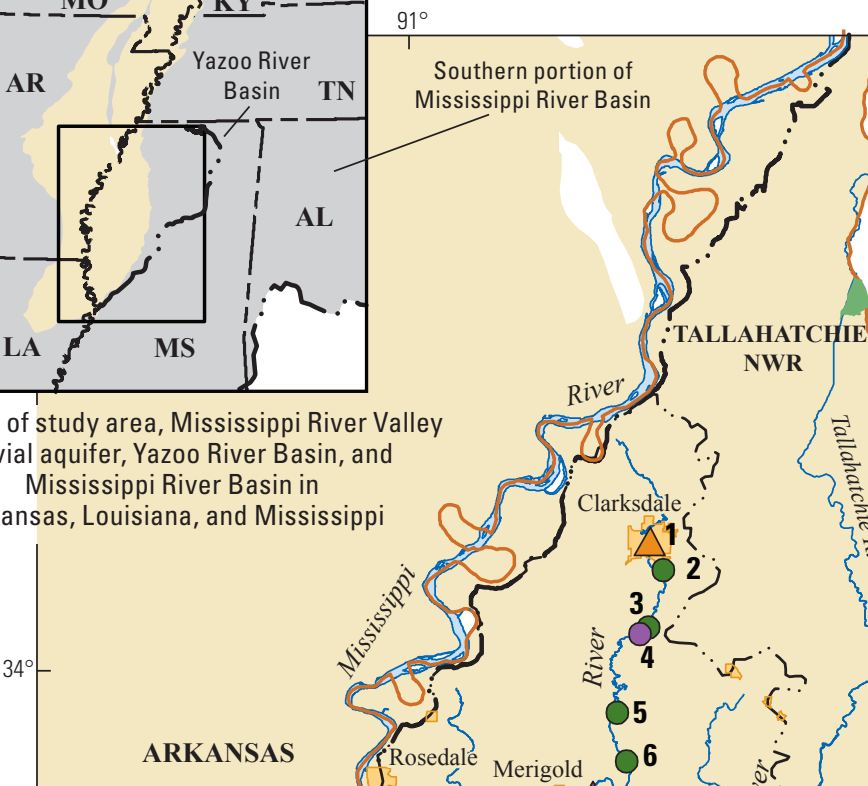

I)
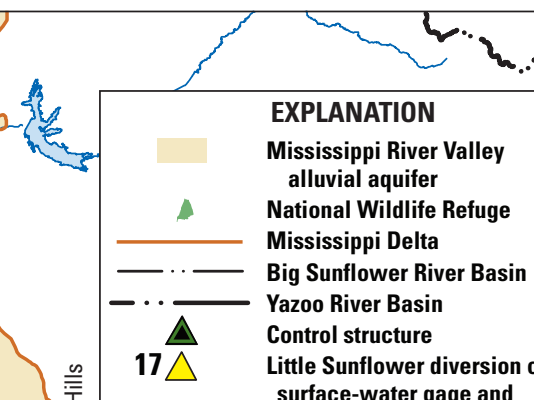

Little Sunflower diversion canal surface-water gage and site number

Big Sunflower River Basin sites

$4 \bigcirc \quad$ Lagrangian sampling site and
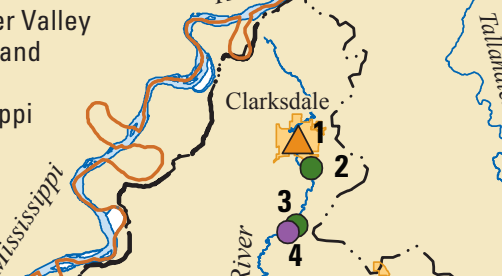

Rosedale Merigold

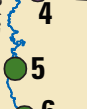

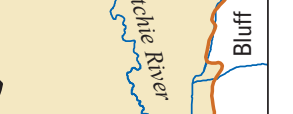

site number

30 May 2011 Lagrangian sampling

1 site and site number

surface-water gage and

7 site number

7 Surface-water gage and


Figure 1. Location of study area and sampling locations with map identification number and extents of the Yazoo River and Big Sunflower River Basins and the Mississippi River Valley alluvial aquifer. Sampling site descriptions are provided in table 1. 


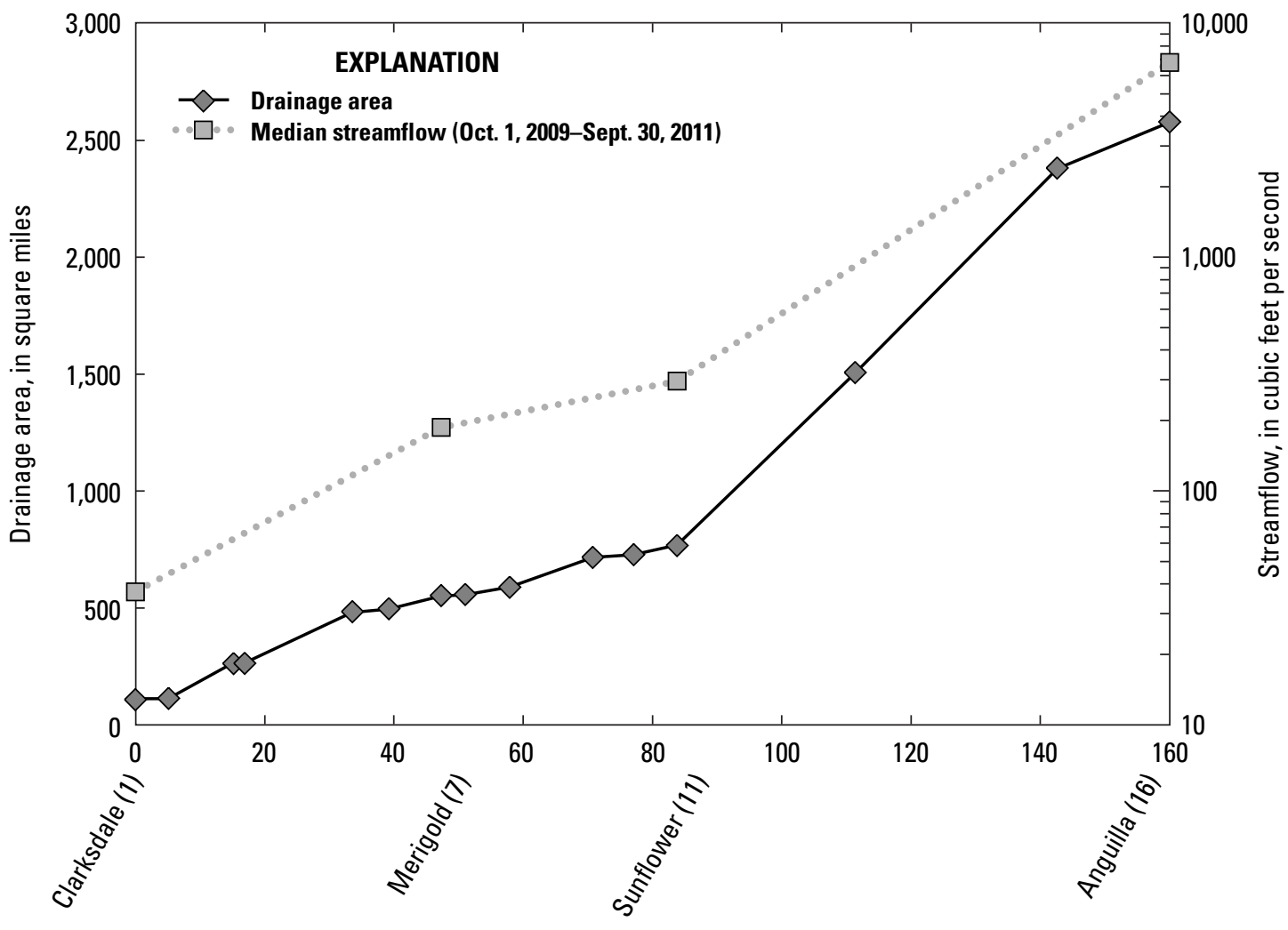

Distance from Clarksdale, in miles

Figure 2. Drainage area along the Big Sunflower River and median streamflow for each of the four gaging stations throughout the study period (0ct. 1, 2009-June 1, 2011). Distance is relative to the Clarksdale gaging station. Gaging stations are labeled along the $x$-axis and the numbers in parenthesis denote the map identification numbers on figure 1 and in table 1.

productive and economically important to the State of Mississippi (Economic Research Service, U.S. Department of Agriculture, 2013). Fertile soils, a long growing season, an average annual rainfall of more than 52 inches (in.), and a plentiful source of irrigation water (the Mississippi River Valley alluvial aquifer) combine to make this region ideal for agriculture. Primary crops grown within the basin include soybean, corn, cotton, and rice, and with the exception of the Panther Swamp and Dahomey National Wildlife Refuges (fig. 1), row-crop agriculture is the dominant land use within the basin.

\section{Hydrologic Setting}

The Big Sunflower River Basin is the largest basin contributing to the Yazoo River and encompasses approximately 4,200 square miles $\left(\mathrm{mi}^{2}\right)$ in the center of the Mississippi Delta - the local term for that part of the Yazoo River Basin contained within the predevelopment Mississippi River floodplain (fig. 1). Over a distance of 160 miles (mi) from Clarksdale, Miss., upstream (USGS station 07288000), to Anguilla, Miss., downstream (station 07288700, table 1), the drainage area of the Big Sunflower River expands from approximately
108 to $2,600 \mathrm{mi}^{2}$ and the median daily streamflow increased from 37 to 6,809 cubic feet per second $\left(\mathrm{ft}^{3} / \mathrm{s}\right)$ based on the period from October 1, 2009, to June 1, 2011 (fig. 2).

Two control structures are located on tributaries to the Yazoo River downstream of the confluence of the Big Sunflower River, and both structures are used to prevent flooding of the lower Yazoo River Basin by the Mississippi River during high water (fig. 1). Both control structures were constructed in 1969 to manage flow from the interior Delta to the Yazoo River. The first control structure, the Little Sunflower River control structure, is located between the Little Sunflower diversion canal and Yazoo River and is approximately $40 \mathrm{mi}$ downstream from Anguilla. The structure is closed during normal operation but open during periods of high flow along the Big Sunflower River. The second control structure, the Steele Bayou control structure, is located between Steele Bayou and the Yazoo River and is approximately 15 mi downstream from the Little Sunflower River control structure. The Steele Bayou control structure is open during normal operation, allowing water to flow into the Yazoo River, but is closed during periods of high flow along the Mississippi River to prevent reverse flow into the Yazoo River Basin. 


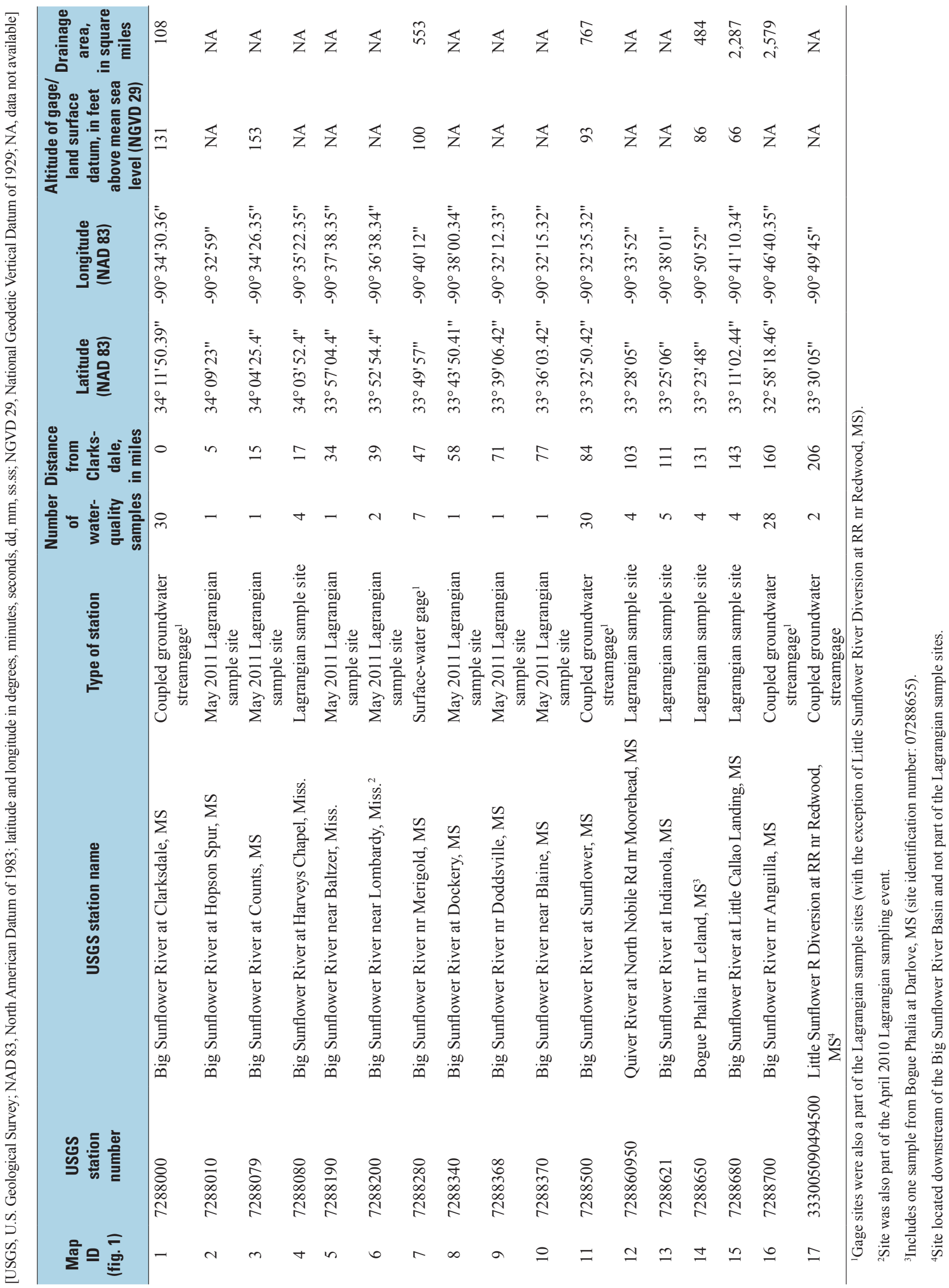


Figure 3. Nitrogen load (in kilograms per year) by source in the Big Sunflower River Basin and percentages of total load. Data from Spatially Referenced Regressions on Watershed attributes (SPARROW) model developed for streams in the southcentral United States (http://cida.usgs. gov/sparrow/map.jsp?model=35, based on work by Rebich and others, 2011).

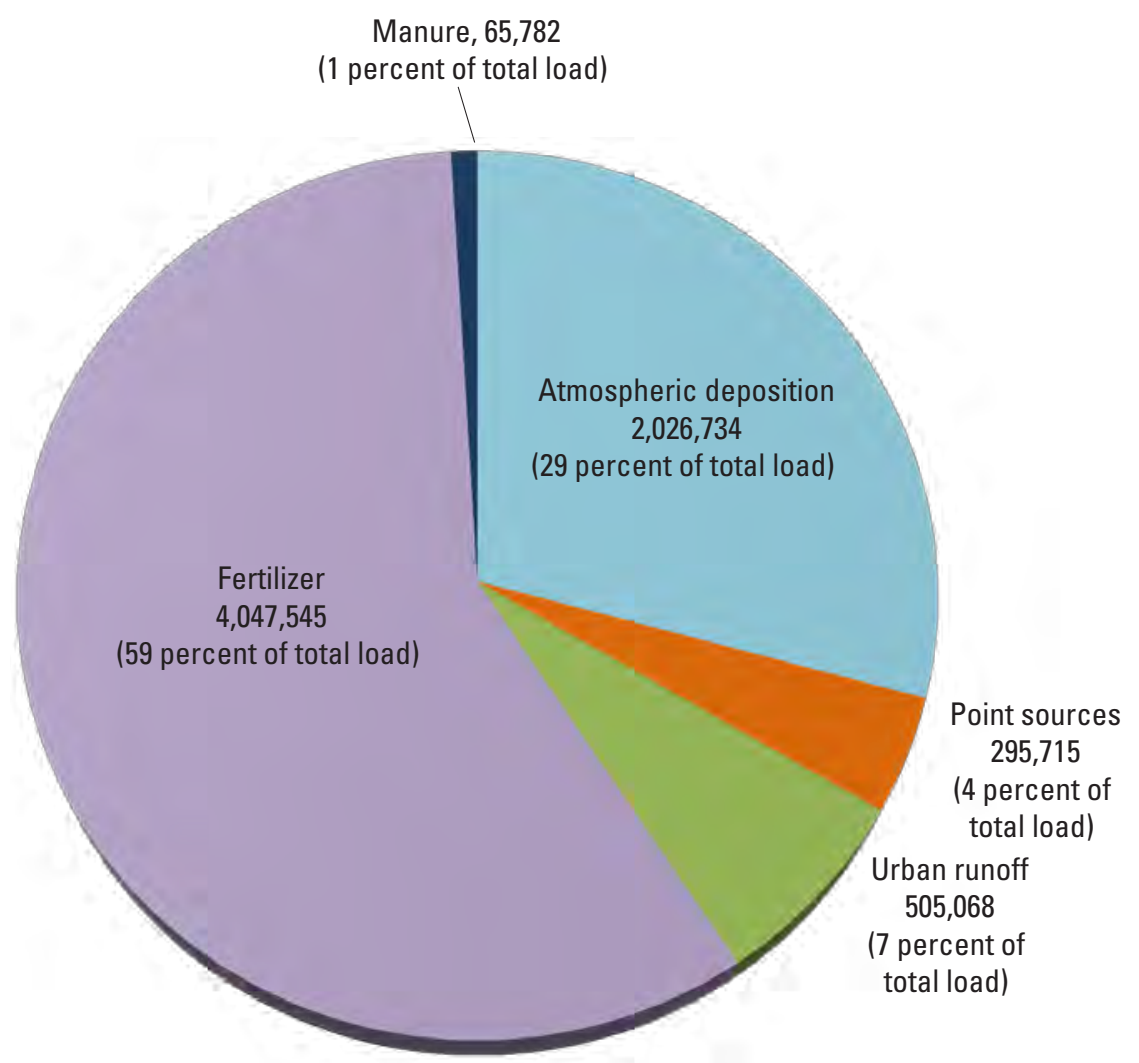

The Big Sunflower River incises the Mississippi River Valley alluvial aquifer (hereafter referred to as the alluvial aquifer), which is the principal aquifer for the region. Historically, the regional groundwater flow path of the alluvial aquifer was composed of two components that flowed from the north to the south and from the eastern and western peripheries toward the center of the Delta. These flow paths generally followed the topography of the alluvial plain, which slopes from north to south and is bounded by the levees of the Mississippi River to the west and the Bluff Hills to the east, both topographic highs relative to the interior of the Delta (Arthur, 2001). Presently, the regional groundwater flow path is intercepted by a large cone of depression in the middle of the Delta that formed in the alluvial aquifer as a result of groundwater withdrawals for irrigation. Streamflow in the Big Sunflower River has been altered in this area by loss of base flow because of declining water levels in the underlying alluvial aquifer (Barlow and Clark, 2011).

\section{Nitrogen Sources}

Nitrogen load within the Big Sunflower River Basin is primarily from fertilizer application and atmospheric deposition, with smaller amounts from urban runoff, point sources, and manure (fig. 3). Atmospheric deposition can be assumed to be relatively evenly distributed within the scale of the Big Sunflower River Basin. Fertilizer application varies by crop type; however, the distribution of the dominant crops (soybean, corn, cotton, and rice) is fairly homogeneous throughout the basin (fig. 4). Therefore, it was assumed in this study that (1) sources of nitrogen are relatively uniform within the study area, and (2) measured differences of nitrogen in the water column reflect changes due to transport, delivery, and processing (that is, denitrification, immobilization, and mineralization).

\section{Nitrogen Cycling}

Nitrogen is required by all organisms as a basic element of all amino acids. Nitrogen exists in organic and inorganic forms; the inorganic form is available for use by plants and microbes, and the organic form is generated when plants and (or) microbes assimilate inorganic nitrogen, converting it to organic nitrogen. Nitrogen is one of the most abundant elements in the Earth's atmosphere but not readily available biologically because the majority of nitrogen is present as $\mathrm{N}_{2}$, an inert gas unavailable for use by organisms. Nitrogen fixation occurs when nitrogen gas is converted to forms generally available for biological uptake. Reactive or biologically available forms of nitrogen are naturally produced by lightning and biological fixation and existed in the environment in lower concentrations prior to anthropogenic inputs. Global increases in reactive nitrogen caused by increases in the amount of nitrogen fixing crops, fossil fuel combustion, and fertilizer production, have led to an increase in reactive nitrogen in the environment. This increase can have detrimental ecological 


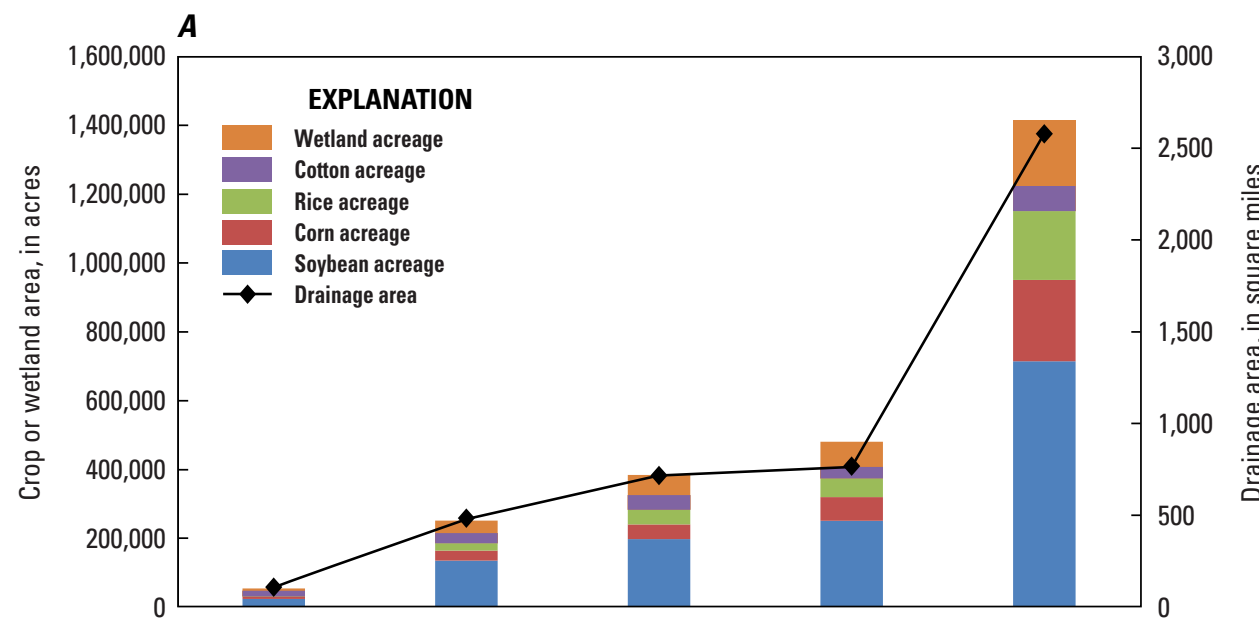


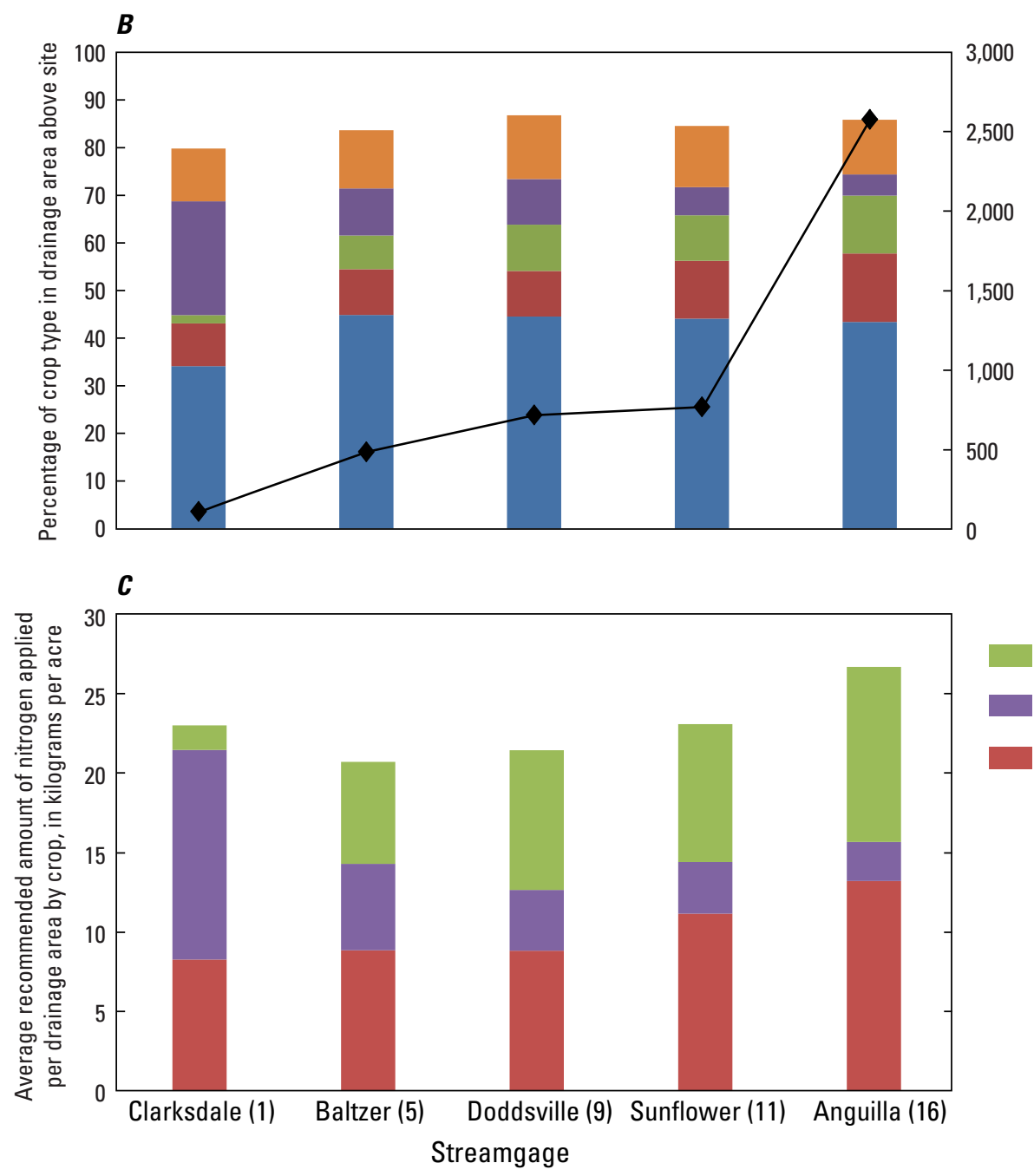

\section{EXPLANATION}

Rice-acreage applied nitrogen per drainage area

Cotton-acreage applied nitrogen per drainage area

Corn-acreage applied nitrogen

per drainage area

Figure 4. A, Total crop area, $B$, relative percentage of dominant crop types within the Big Sunflower River Basin, and $C$, average recommended amount of nitrogen applied per drainage area by crop. Source for crop acreage: http://www.nass.usda.gov/Statistics_by_State/Mississippi/index.asp; accessed January 24, 2011. Recommended nitrogen fertilizer application rates provided by Mississippi State University Department of Agricultural Economics (2009). Numbers in parenthesis denote the map identification numbers on figure 1 and in table 1. 
and human health effects such as the development of the zone of hypoxia in the northern Gulf of Mexico each summer as a result of nutrient input from the Mississippi River. Such effects are further compounded as reactive nitrogen moves from one part of the environment to another in a process referred to as the nitrogen cascade (Galloway and others, 2003). The nitrogen cascade describes the movement of reactive nitrogen through the Earth's atmosphere, hydrosphere, and biosphere, and the multiple effects that reactive nitrogen can have on terrestrial, freshwater, and marine systems, as well as human health.

Agricultural areas receive 75 percent of anthropogenic inputs of reactive nitrogen and although the majority of nitrogen is assimilated by crops (immobilization), some is lost to other areas (Galloway and others, 2003). The fate of this unassimilated, reactive nitrogen depends on the residence time, rates of uptake, and denitrification potential within an area (Seitzinger and others, 2006). Immobilization reduces the amount of reactive inorganic nitrogen by converting it to organic forms; this process can be reversed, however, and returned to reactive forms by mineralization or ammonification (Galloway and others, 2003). The reduction of nitrate $\left(\mathrm{NO}_{3}^{-}\right)$to nitrous oxide $\left(\mathrm{N}_{2} \mathrm{O}\right)$ or nitrogen gas $\left(\mathrm{N}_{2}\right)$, or denitrification, may produce a substantial loss of reactive nitrogen moving through aquatic ecosystems. This process requires anoxic or oxygen-limited conditions and relies on specific bacteria adapted to gain energy by reducing nitrogen, as an electron acceptor, in order to oxidize available organic and inorganic compounds, as electron donors (Delwiche and Bryan, 1976; Seitzinger and others., 2006).

\section{Methods of Investigation}

\section{Description of Sampling Sites}

Water samples were collected from 16 sites located on the Big Sunflower River and on major tributaries to the Big Sunflower River between October 1, 2009, and June 1, 2011 (fig. 1). Four of these sites were located on the main stem at continuous streamgages and all but one included nearby piezometers to record groundwater levels (fig. 1). The four continuously gaged sites are described here.

\section{Big Sunflower River at Clarksdale, Mississippi}

The Big Sunflower River at Clarksdale, MS streamgage (site 1, table 1) is near the headwaters of the Big Sunflower River within the city of Clarksdale. The channel is cut into the alluvial aquifer, consisting of silt and fine-grained sand. The drainage area above this point is $108 \mathrm{mi}^{2}$. Mean daily streamflow during the study period ranged from 5.9 to $4,630 \mathrm{ft}^{3} / \mathrm{s}$ and averaged $172 \mathrm{ft}^{3} / \mathrm{s}$. The stream channel is approximately $15 \mathrm{feet}(\mathrm{ft}$ ) deep and $240 \mathrm{ft}$ wide at bank full.

\section{Big Sunflower River near Merigold, Mississippi}

The Big Sunflower River near Merigold, MS streamgage (site 7, table 1) is located approximately $47 \mathrm{mi}$ downstream from the gage at Clarksdale. The channel is cut into alluvium consisting of fine- to medium-grained sand. The drainage area above this point is $553 \mathrm{mi}^{2}$. Mean daily streamflow during the study period ranged from 22.3 to $6,510 \mathrm{ft}^{3} / \mathrm{s}$ and averaged $834 \mathrm{ft}^{3} / \mathrm{s}$. The stream channel is approximately $20 \mathrm{ft}$ deep and $230 \mathrm{ft}$ wide at bank full.

\section{Big Sunflower River at Sunflower, Mississippi}

The Big Sunflower River at Sunflower, MS streamgage (site 11, table 1) is located in the central part of the Big Sunflower River Basin and is approximately 84 mi downstream from the gage at Clarksdale. The channel is cut into alluvium consisting of fine- to medium-grained sand. The drainage area above this point is $767 \mathrm{mi}^{2}$. Mean daily streamflow during the study period ranged from 20.1 to $6,570 \mathrm{ft}^{3} / \mathrm{s}$ and averaged $1,050 \mathrm{ft}^{3} / \mathrm{s}$. The stream channel is approximately $30 \mathrm{ft}$ deep and $255 \mathrm{ft}$ wide at bank full.

\section{Big Sunflower River near Anguilla, Mississippi}

The Big Sunflower River near Anguilla, MS streamgage (site 16, table 1) is located in the southern part of the Big Sunflower River Basin and is approximately $160 \mathrm{mi}$ downstream from the gage at Clarksdale. The channel is cut into alluvium consisting of silt and fine-grained sand. The drainage area above this point is $2,579 \mathrm{mi}^{2}$. Mean daily streamflow during the study period ranged from 367 to $25,200 \mathrm{ft}^{3} / \mathrm{s}$ and averaged $8,290 \mathrm{ft}^{3} / \mathrm{s}$. The stream channel is approximately $30 \mathrm{ft}$ deep and $600 \mathrm{ft}$ wide at bank full.

\section{Sample Collection and Analysis}

Periodic samples were collected at near-monthly intervals at each of the streamgages along the Big Sunflower River except at Merigold, which was sampled less frequently (table 1). Two depth-integrated samples and dissolved oxygen measurements were also taken at one site on the Little Sunflower Diversion Canal during June 2010 (site 17, fig. 1, table 1). This site was located approximately 6 mi upstream of the SB Control Structure and 46 mi downstream from the Big Sunflower near Anguilla streamgage. Water samples and measurements of dissolved oxygen were collected on the diversion canal just before and 8 days after the SB Control Structure was closed to control backwater flooding for the Mississippi. All samples were collected according to established procedures described in the USGS National Field Manual for the Collection of Water-Quality Data (U.S. Geological Survey, variously dated).

Water samples were analyzed for nutrients (nitrate-plusnitrite, ammonia, and organic and total nitrogen) and chloride; 
physical properties (dissolved oxygen, $\mathrm{pH}$, specific conductance, temperature, turbidity, and alkalinity) were measured during sample collection. Groundwater samples for inorganic analysis were preserved with 7.5-N nitric acid. Surface-water samples for nutrient analysis were preserved with $4.5-\mathrm{N}$ sulfuric acid. Samples were then chilled on ice and shipped by means of next-day delivery for analysis using approved analytical methods. Samples were sent to either the USGS National Water-Quality Laboratory (NWQL) in Denver, Colorado, or the Mississippi Department of Environmental Quality (MDEQ) laboratory in Pearl, Miss. Concentrations of chloride, ammonia, nitrate-plus-nitrite, and ammonia-plus-organic nitrogen were determined at both laboratories using atomic absorption, inductively-coupled plasma mass spectrometry, ion-chromatography, ion specific electrodes, and colorimetric methods, as described in Fishman and Friedman (1989) and Fishman (1993). Concentrations of organic nitrogen for each sample were calculated by subtracting the concentration of ammonia from the concentration of ammonia-plus-organic nitrogen. Concentrations of total nitrogen for each sample were calculated by summing the concentrations of ammonia, nitrate-plus-nitrite, and organic nitrogen.

\section{Lagrangian Sampling}

Lagrangian sampling was conducted at various times and scales to quantify total nitrogen transport along the Big Sunflower River and its major tributaries. As defined, a Lagrangian sampling scheme is designed to follow a single, discrete volume of water through time to determine how its quality changes as it moves downstream (Moody, 1993; Battaglin and others, 2001). The timing of successive samples at locations downstream is based on the anticipated rate of movement, or travel time, of the study volume between locations. Travel times on the Big Sunflower River were estimated based on continuous streamflow at gages and specific discharge and average velocity measurements made at upstream locations. From April through August 2010, Lagrangian sampling was conducted four times on the Big Sunflower River from Clarksdale, Miss., to Anguilla, Miss. (fig. 1): (1) April 8-April 21, (2) May 12-June 3, (3) June 15-July 1, and (4) August 23August 30. A fifth sample was collected the following spring from May 16 to May 20, 2011. These periods were chosen to represent the majority of the growing season in the Mississippi Delta when almost all fertilizer is applied.

Lagrangian sampling generally began at the top of the reach (Clarksdale) and continued downstream to Anguilla or Sunflower. Because of logistical constraints, the August 2010 sampling was done simultaneously on three sub-reaches between Clarksdale and Anguilla; one between Clarksdale and Merigold (Reach 1), a second between Merigold and Indianola (Reach 2), and a third between Indianola and Anguilla (Reach 3). Lagrangian samples collected in May 2011 concentrated on the upper end of the Big Sunflower River, beginning in Clarksdale, Miss. (site 1) and ending in Sunflower,
Miss. (site 11) (fig. 1, table 1). In order to better quantify the transport of nitrate throughout this reach, additional sites were sampled during the May 2011 effort (fig. 1).

\section{Statistical Analysis}

The Kruskal-Wallis analysis of variance (Helsel and Hirsch, 1992) was used to test for the presence of significant differences in nitrogen concentrations among sites and sampling events on the Big Sunflower River. As a nonparametric test, Kruskal-Wallis does not assume a normal distribution of residuals and is well-suited to analyses of water-quality sample sets. A 5-percent level of significance $(\rho<0.05)$ was required to infer the presence of differences among sites or events. Where differences could be associated with sites and events, a Tukey's multiple comparison test (Helsel and Hirsch, 1992) was used to test specific differences among sites and groups of sites. Pearson's $r$ was used to test for correlation between nitrogen and physical properties.

\section{Occurrence of Nitrogen in the Big Sunflower River}

Between October 1, 2009, and June 30, 2011, a total of 95 periodic samples were collected at four streamgages along the Big Sunflower River (listed here in downstream order): Clarksdale, Merigold, Sunflower, and Anguilla. Samples were collected over a range of streamflow conditions, which were generally within the total range of streamflow conditions for the study period (fig. 5 and appendix 1). Graphs of streamflow and the concentrations of total nitrogen and each of its components, organic nitrogen, ammonia, and nitrate plus nitrite, indicate both temporal and spatial patterns in these concentrations as well as temporal variation in streamflow at each site (fig. 6). Nitrogen concentrations were generally highest at each site during the spring of the 2010 water year and fall and winter of the 2011 water year although the dominant form varied by site. For example, the concentration of organic nitrogen was generally higher than the concentrations of ammonia and nitrate plus nitrite in samples collected from the most upstream site (Clarksdale), whereas nitrate-plus-nitrite concentrations were generally higher than those of organic nitrogen and ammonia in samples collected farther downstream at the Sunflower and Anguilla sites.

\section{Spatial Comparisons}

Generally, periodic samples indicate that about 95 percent of total nitrogen in the Sunflower River is composed in nearly equal parts of organic and nitrate-plus-nitrite forms but that the ratio of these two forms shifts from greater organic nitrogen upstream to greater nitrate-plus-nitrite nitrogen downstream 


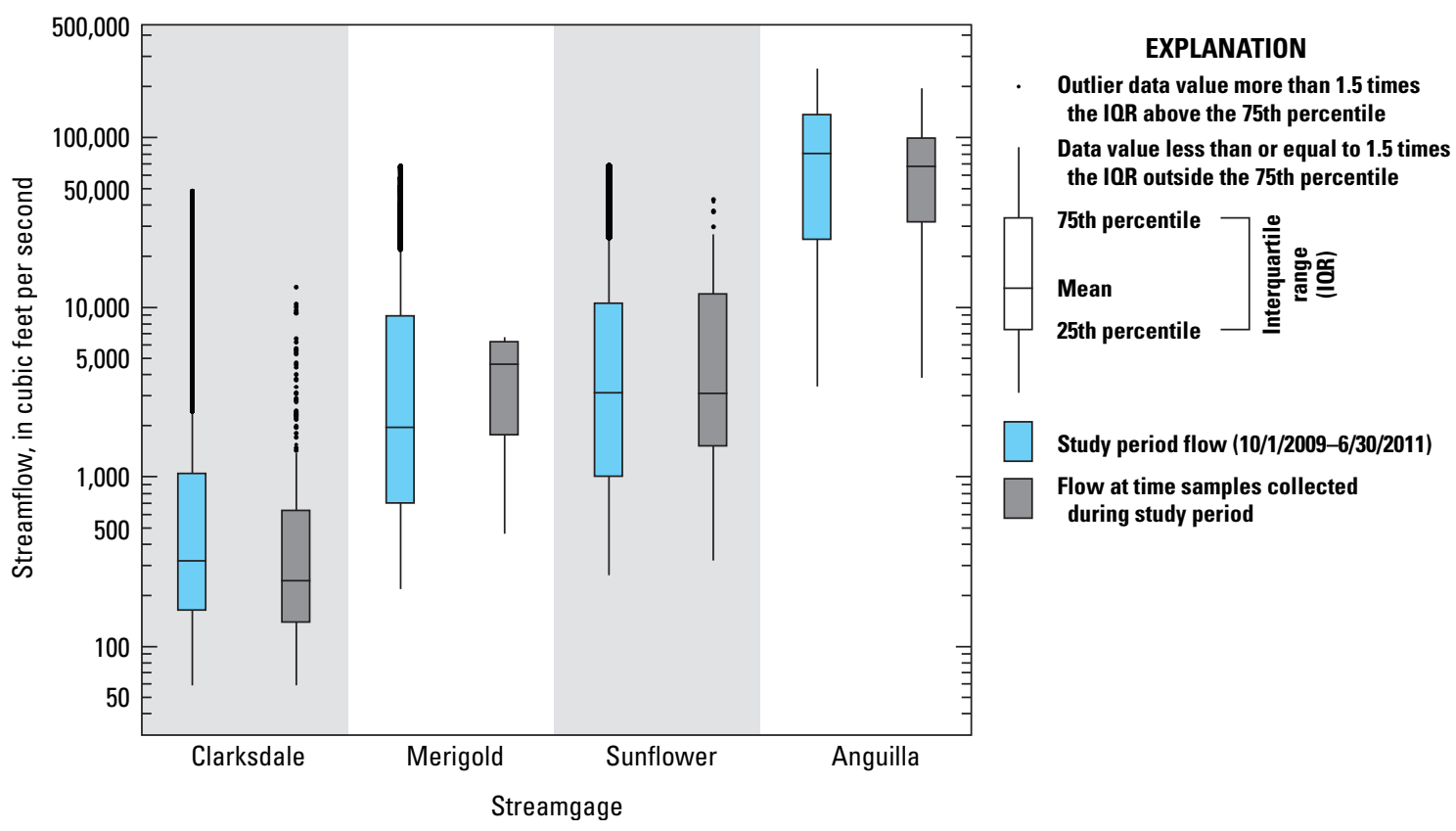

Figure 5. Distribution of streamflow at the time samples were collected in comparison to the distribution of streamflow throughout the study period (Oct. 1, 2009-June 30, 2011).

(fig. 7). Nitrogen concentrations for all sites ranged between 0.065 and 4.9 milligrams per liter $(\mathrm{mg} / \mathrm{L})$ for total nitrogen, $<0.07$ and $3.3 \mathrm{mg} / \mathrm{L}$ for organic nitrogen, $<0.02$ and $3.44 \mathrm{mg} / \mathrm{L}$ for nitrate plus nitrite, and only $<0.04$ and $0.42 \mathrm{mg} / \mathrm{L}$ for ammonia. Statistical comparisons of nitrogen concentrations among sites did not include Merigold because of the low number of samples collected there. Concentrations of total nitrogen, ammonia, and nitrate plus nitrite differed significantly $(\rho<0.05)$ among sites, whereas organic nitrogen concentration did not differ significantly between any of the sites (fig. 7). Median concentrations of total nitrogen and nitrate plus nitrite in samples collected from the three sites increased between Clarksdale and Anguilla. In contrast, the median concentration of ammonia was highest in samples collected from Clarksdale and concentrations of organic nitrogen were comparable between sites, indicating that the increase in the median concentration of total nitrogen between Clarksdale and Anguilla is related to increases in nitrate plus nitrite concentration and not related to variation in organic nitrogen or ammonia concentration. Further study would be required to determine the source of the nitrate plus nitrite increase in the Big Sunflower River between Clarksdale and Sunflower.

\section{Seasonal Comparisons}

Although median concentrations of total nitrogen when aggregated across all sites appear highest in the spring, results from the Kruskal-Wallis test fail to show a significant difference among seasons $(\rho=0.1311)$, The apparent seasonality of nitrogen concentrations in various forms in the Big Sunflower River can be seen in time-series plots (fig. 6) and in box plots showing nitrogen concentrations and the ratio of each form of nitrogen to total nitrogen, grouped by season (fig. 8). Concentrations of organic nitrogen, ammonia, and nitrate plus nitrite were significantly different between at least two seasons. Median concentrations of ammonia and nitrate plus nitrite were highest during the winter and spring months, whereas median concentrations of organic nitrogen were highest during the fall and spring months, indicating a potential difference in source between ammonia and nitrate plus nitrite compared to organic nitrogen during the fall and winter months (fig. 8). Percent organic nitrogen and nitrate plus nitrite were significantly different between at least two seasons, caused primarily by the relatively low concentrations of ammonia, and therefore, relatively low contribution to total nitrogen in the Big Sunflower River. Concentrations of nitrate plus nitrite and organic nitrogen are an order of magnitude higher than concentrations of ammonia and have a correspondingly greater influence on total nitrogen concentration.

\section{Correlation of Nitrogen Concentrations with Streamflow and Physical Properties}

With the exception of water temperature, streamflow and other physical properties measured (specific conductance, dissolved oxygen, $\mathrm{pH}$, and turbidity) were significantly correlated with concentrations of at least one form of nitrogen (table 2). The magnitude and significance of the correlation coefficient can be related to various processes. For example, the positive significant correlation between streamflow and nitrate plus nitrite can be explained by transport processes, in that nitrate 


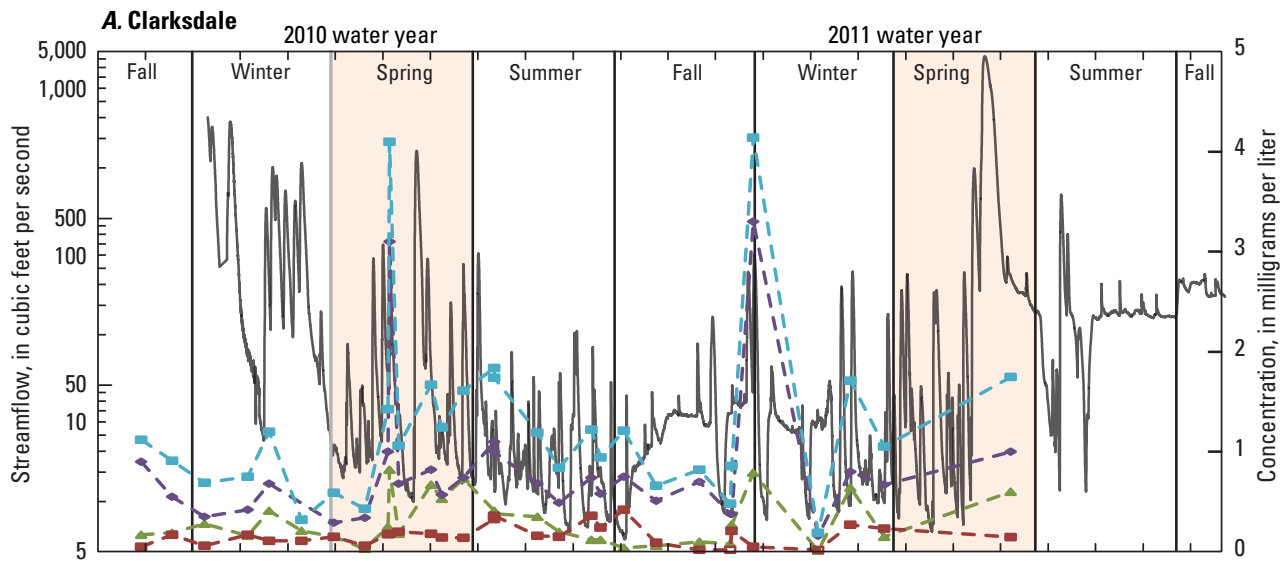

B. Merigold

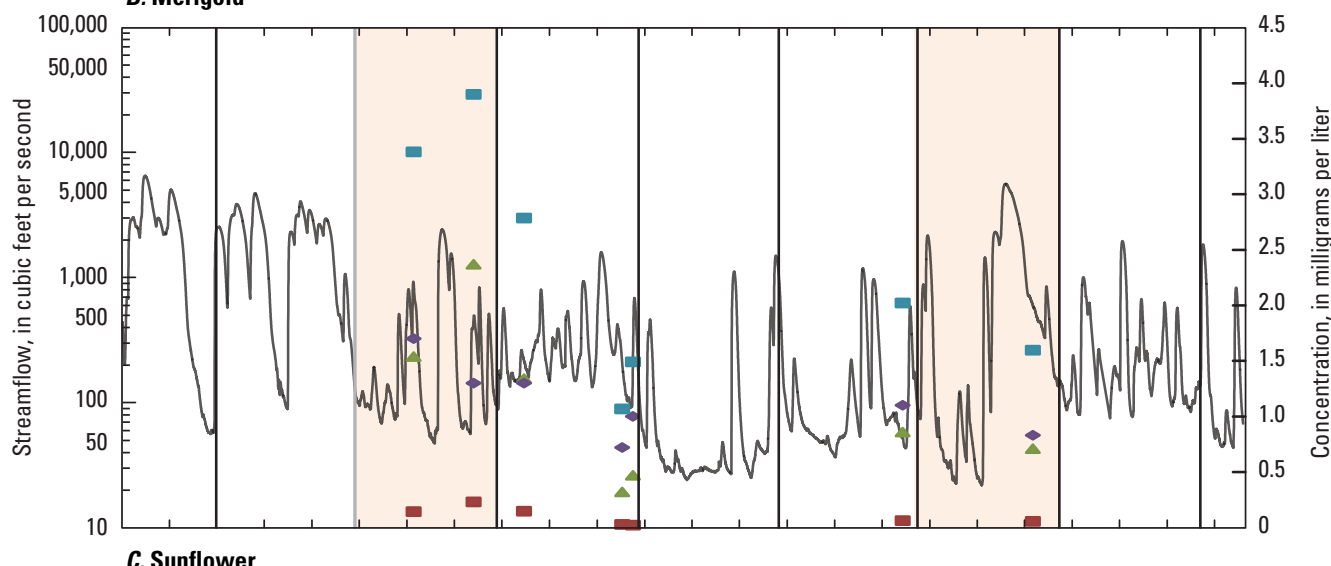

EXPLANATION
- Streamflow
-- Nitrate plus nitrite

$-\downarrow-$ Organic nitrogen

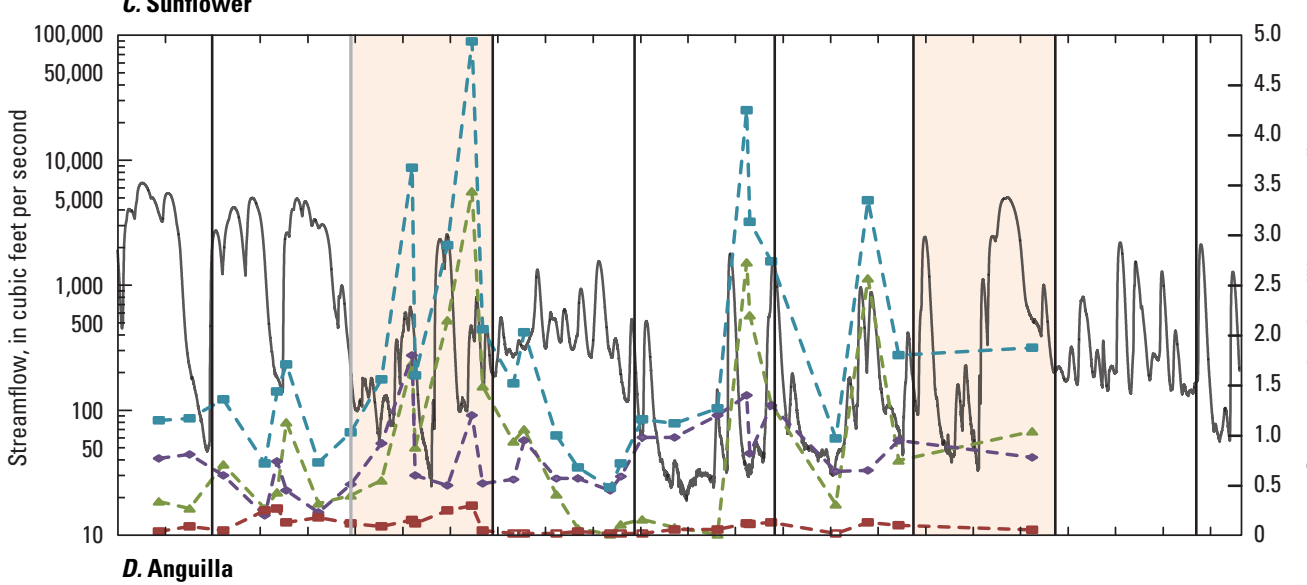

- - Ammonia

- - - Total nitrogen

Fertilizer application

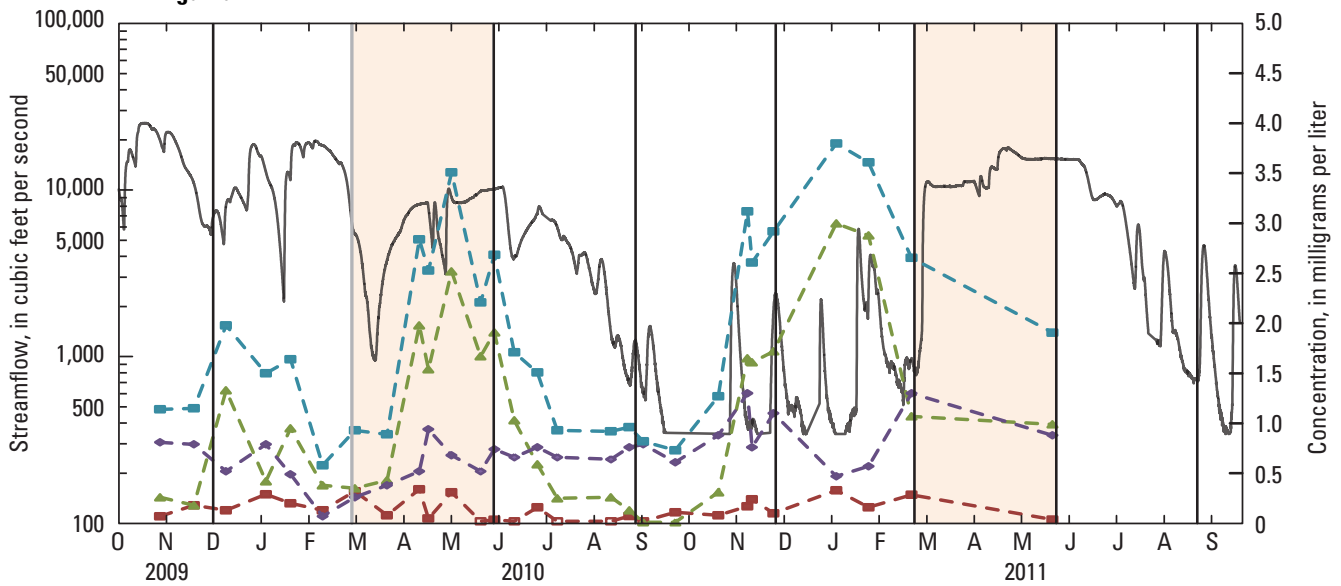

Figure 6. Streamflow and concentrations of total nitrogen, organic nitrogen, ammonia, and nitrate plus nitrate for each of the four regularly sampled streamgage sites on the Big Sunflower River. 

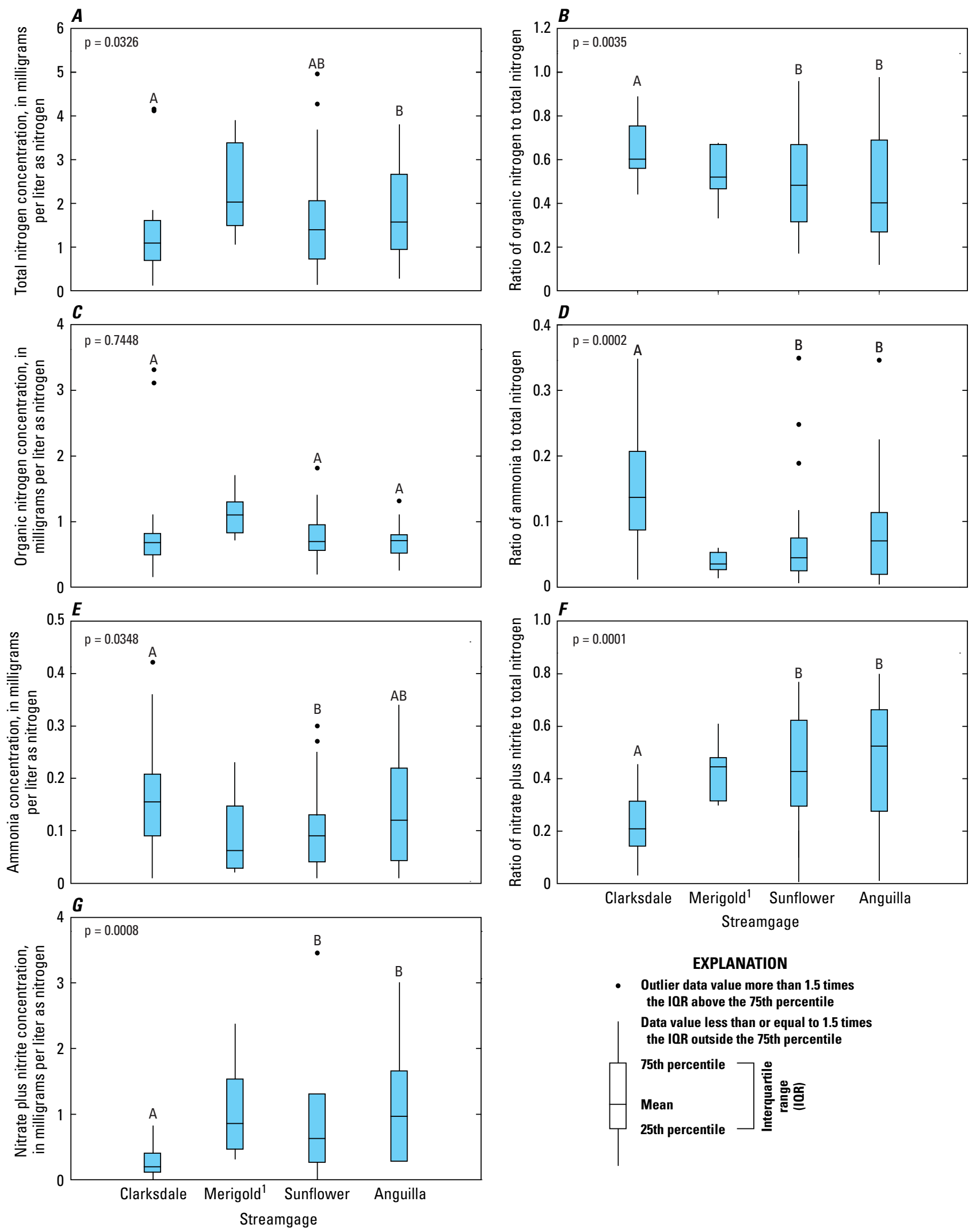

EXPLANATION

- Outlier data value more than 1.5 times the IOR above the 75th percentile Data value less than or equal to 1.5 times the IOR outside the 75th percentile

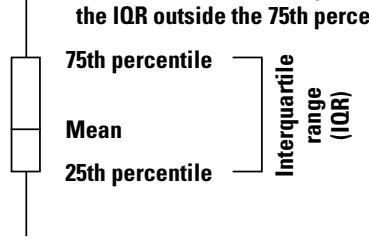

Figure 7. Distribution of concentrations of total nitrogen, organic nitrogen, ammonia, and nitrate plus nitrite and the ratio of each form of nitrogen to total nitrogen at each of the regularly sampled streamgage sites. Kruskal-Wallis $\rho$-value provided in upper left hand corner of each graph. Results from the Tukey multiple comparison test indicated by letters above each box plot; means for groups with the same letter are not significantly different from each other at $\alpha=0.05$. 'Data from the Merigold site were not included in the statistical analysis due to the relatively low number of samples. 

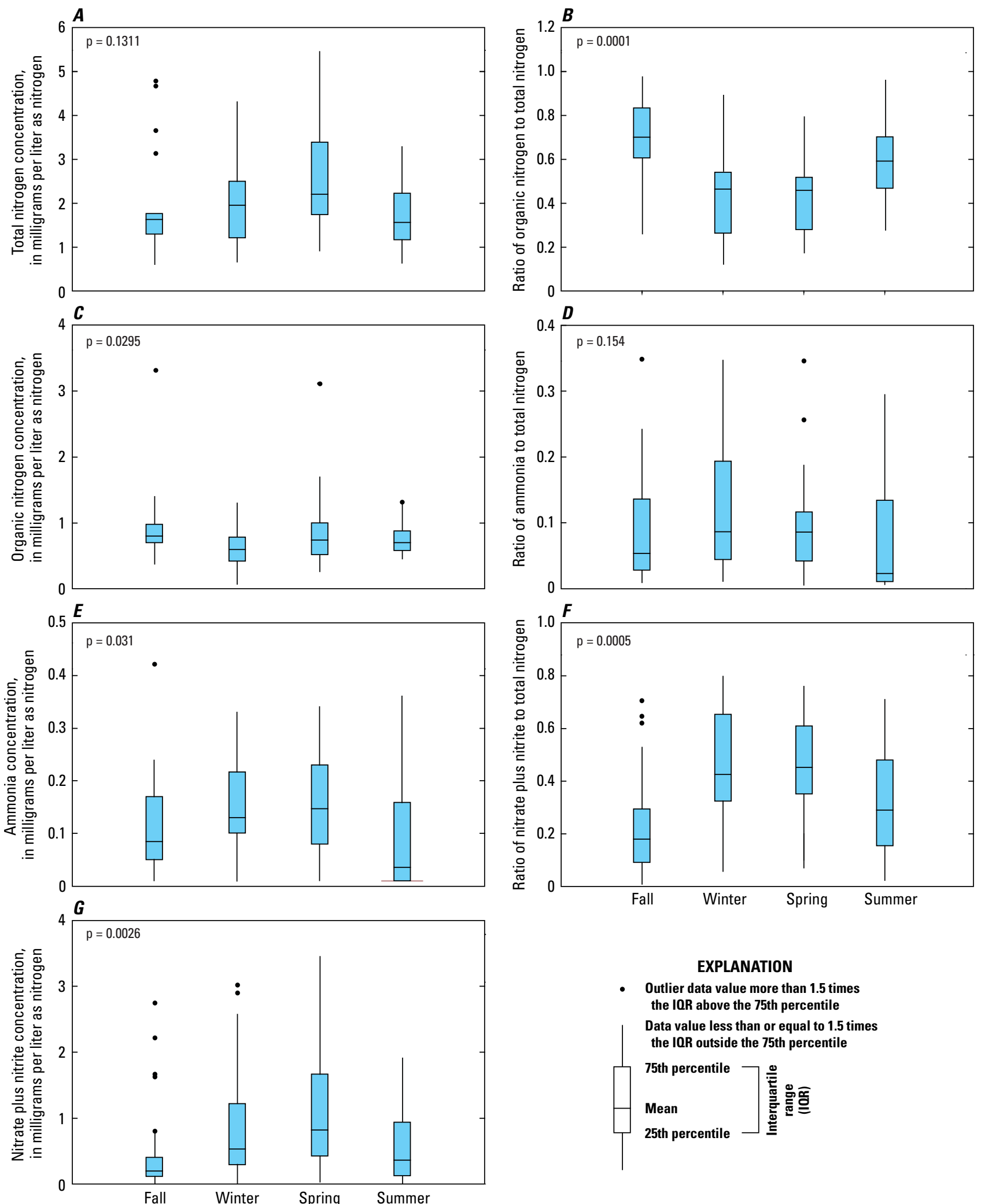

EXPLANATION

- Outlier data value more than 1.5 times the IQR above the 75th percentile Data value less than or equal to 1.5 times the IOR outside the 75th percentile

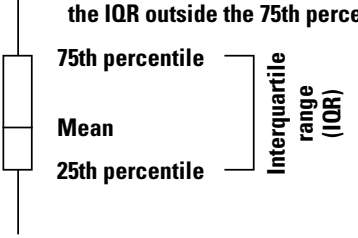

Figure 8. Seasonal distribution of concentrations of total nitrogen, organic nitrogen, ammonia, and nitrate plus nitrite and the ratio of each form of nitrogen to total nitrogen in samples collected from the Big Sunflower River between October 1, 2009, and June 30, 2011. Kruskal-Wallis $\rho$-value provided in upper left hand corner of each graph. 
Table 2. Summary statistics for selected physical properties measured the time of sample collection and correlation coefficients between each physical property and concentration of nitrogen.

[A total of 61 samples were collected in each case. $\mathrm{ft} / \mathrm{s}$, cubic foot per second; ${ }^{\circ} \mathrm{C}$, degrees Celsius; $\mu \mathrm{s} / \mathrm{cm}$, microsiemens per centimeter; $\mathrm{mg} / \mathrm{L}$, milligrams per liter; NTU, nephelometric turbidity units]

\begin{tabular}{|c|c|c|c|c|c|c|c|c|}
\hline \multirow{2}{*}{$\begin{array}{l}\text { Physical property } \\
\text { (abbreviation), } \\
\text { and unit of measure }\end{array}$} & \multirow[b]{2}{*}{ Range } & \multirow[b]{2}{*}{ Median } & \multirow[b]{2}{*}{ Mean } & \multirow{2}{*}{$\begin{array}{l}\text { Standard } \\
\text { deviation }\end{array}$} & \multicolumn{4}{|c|}{ Correlation coefficient ${ }^{1}$} \\
\hline & & & & & $\begin{array}{c}\text { Total } \\
\text { nitrogen }\end{array}$ & $\begin{array}{l}\text { Organic } \\
\text { nitrogen }\end{array}$ & Ammonia & $\begin{array}{c}\text { Nitrate plus } \\
\text { nitrite }\end{array}$ \\
\hline Water temperature (WT), ${ }^{\circ} \mathrm{C}$ & $0.5-33.7$ & 21.55 & 20.42 & 9.09 & $-0.08(0.533)$ & $-0.05(0.717)$ & $-0.08(0.547)$ & $-0.08(0.533)$ \\
\hline Specific conductance (SC), $\mu \mathrm{s} / \mathrm{cm}$ & $55-549$ & 270.50 & 292.40 & 135 & $-0.35(0.005)$ & $-0.21(0.098)$ & $-0.27(0.032)$ & $-0.33(0.009)$ \\
\hline Turbidity (TBY), NTU & $5.5-1,000$ & 80.50 & 141.27 & 191 & $0.56(0.000)$ & $0.70(0.000)$ & $0.11(0.381)$ & $0.30(0.018)$ \\
\hline
\end{tabular}

${ }^{1}$ Level of significance shown in parentheses, significant correlations $(\rho<0.05)$ shown in bold.

plus nitrite is soluble and readily transported by overland flow to the stream. Conversely, the negative significant correlation between specific conductance and total nitrogen, ammonia, and nitrate plus nitrite is also probably related to streamflow and transport. Higher specific conductance values in water correspond to a higher proportion of groundwater having little to no nitrogen in any form and a lower proportion of overland flow. Conversely, lower specific conductance values correspond to lower proportions of groundwater and higher proportions of overland flow having relatively high concentrations of nitrogen. Turbidity was positively correlated with concentrations of all forms of nitrogen and significantly correlated in all cases except for ammonia indicating that total nitrogen, organic nitrogen, and nitrate plus nitrite are potentially transported with sediment by way of overland flow. Ammonia was negatively correlated to dissolved oxygen and $\mathrm{pH}$. This is likely because acidic and anoxic conditions favor the production and conservation of ammonia. At higher $\mathrm{pH}$, ammonia more readily volatilizes; in more oxic conditions, ammonia may oxidize to nitrite and nitrate (nitrification).

Seasonal variation in nitrogen concentration reflected seasonal variations in streamflow and specific conductance. Streamflow in the Big Sunflower River is generally greatest during winter and spring, corresponding with low specific conductance values (fig. 9A-B). Specific conductance can be used as a surrogate for the percentage of groundwater either discharging, or returning as irrigation return flow, to the Big Sunflower River. Groundwater from the underlying alluvial aquifer has a higher specific conductance (200-1,600 microsiemens per centimeter at 25 degrees Celsius $(\mu \mathrm{S} / \mathrm{cm})$; Arthur, 2001) than water entering the stream from precipitation by way of overland runoff. Therefore, high specific conductance values correspond to periods of low streamflow when groundwater inflows compose the majority of streamflow in the Big Sunflower River, and low values of specific conductance correspond to periods of high streamflow. Nitrate is generally absent from groundwater in the underlying alluvial aquifer because of low oxygen conditions conducive to denitrification
(Welch and others, 2011; Barlow and Coupe, 2012). Concentrations of nitrogen in the Big Sunflower River were higher during winter and spring when streamflow was high and composed predominantly of precipitation via overland runoff compared to summer and fall when streamflow was low and composed predominantly of discharged groundwater (figs. 8 and $9 A$ ).

\section{Results of Lagrangian Sampling}

In the first four Lagrangian sampling events, samples were collected at seven sites along the Big Sunflower River from Clarksdale to Anguilla and at two sites along major tributaries (fig. 1). The fifth and final sampling event included 11 sites on the Big Sunflower River from Clarksdale to Sunflower. This reach includes a section of the Big Sunflower River, between Merigold and Sunflower, where streamflow losses were measured based on data collected in the 2010 water year. Streamflow, nitrogen fluxes, and chloride fluxes generally increased with drainage area, with the exception of a losing reach located between Merigold and Sunflower in the central part of the Big Sunflower Basin. Within this reach, streamflow losses were measured concurrent with decreased nitrogen and chloride fluxes, indicating a loss of mass through the streambed.

\section{April 8-21, 2010}

Streamflow ranged from $214 \mathrm{ft}^{3} / \mathrm{s}$ at Clarksdale to $1,080 \mathrm{ft}^{3} / \mathrm{s}$ at Anguilla, generally increasing downstream except between Merigold and Sunflower (fig. 10). Streamflow along this reach, between river mile 47 and mile 84 , decreased 13 percent, from 580 to $502 \mathrm{ft}^{3} / \mathrm{s}$. Inflows from the first major tributary of the Big Sunflower River, the Quiver River, accounted for 96 percent of the increase in streamflow between the two Big Sunflower River stations upstream and downstream of the Quiver River confluence, site 11 at mile 84 

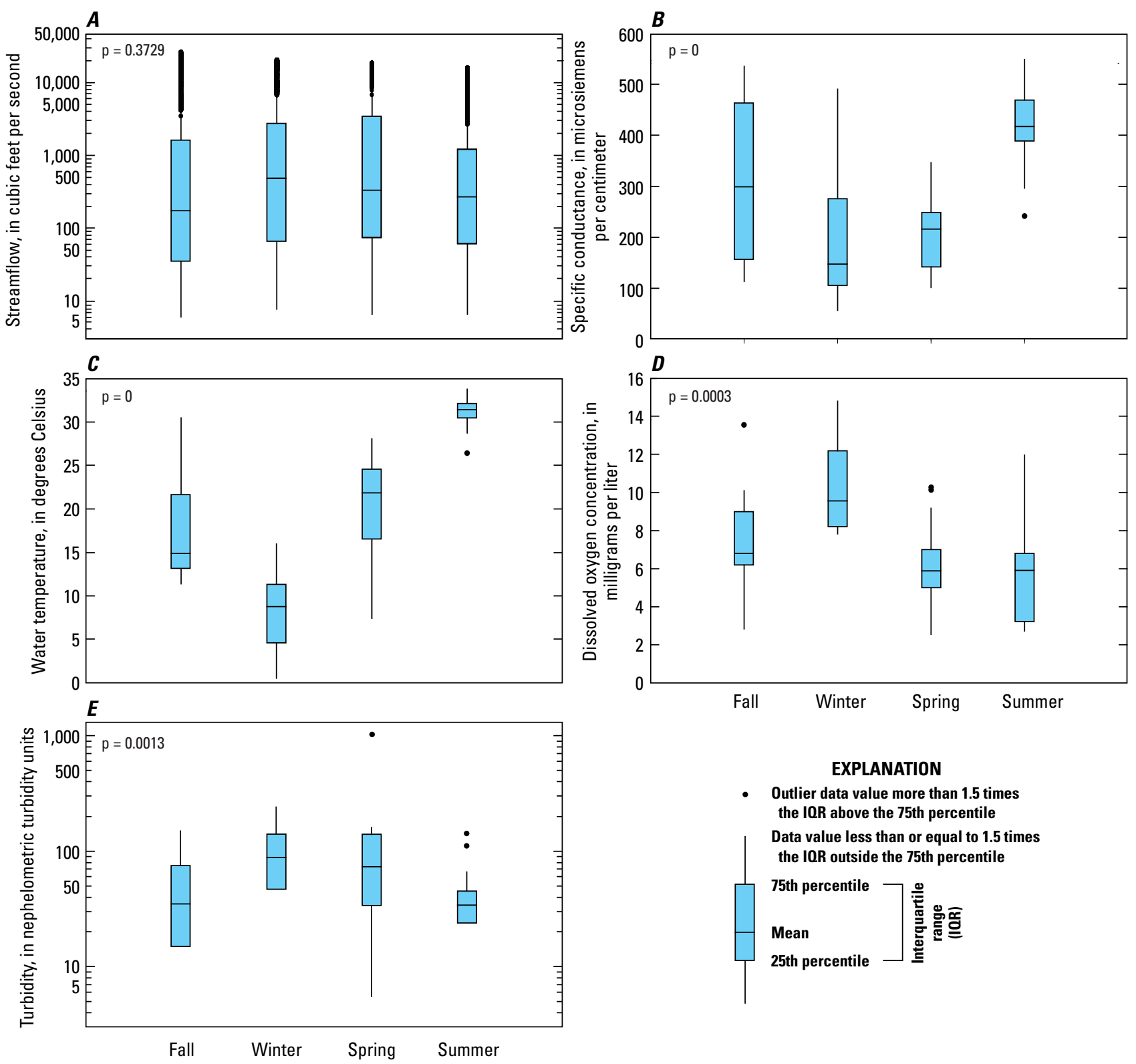

EXPLANATION

- Outlier data value more than 1.5 times the IOR above the 75th percentile

Data value less than or equal to 1.5 times the IQR outside the 75th percentile

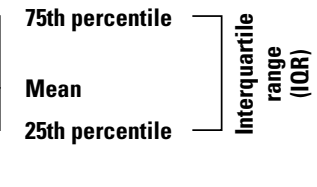

Figure 9. Seasonal distribution of streamflow, specific conductance, water temperature, dissolved oxygen, and turbidity in the Big Sunflower River between October 1, 2009, and June 30, 2011. Kruskal-Wallis $\rho$-value provided in upper left hand corner of each graph.

and site 13 at mile 111, respectively (figs. 1 and 10). Contributions from the second major tributary to the Big Sunflower River, the Bogue Phalia, accounted for more than 107 percent of the increase in streamflow between the two Big Sunflower River stations upstream and downstream of the Bogue Phalia confluence, site 13 at mile 111 and site 15 at mile 143 . The downstream increase in streamflow measured between these two stations was relatively small and could be due to timing errors associated with either under- or over-predicting the transit time of the tagged water parcel.

The flux of total nitrogen increased downstream between Clarksdale and Anguilla (fig. 11A), except for the net loss between Merigold and Sunflower and between Indianola and Little Callao. The decrease in the flux of total nitrogen between Merigold and Sunflower was concurrent with a decrease in streamflow (fig. 10) and small increase in total nitrogen concentration (fig. 11B), whereas the decrease in the flux of total nitrogen between Indianola and Little Callao was concurrent with a small increase in streamflow (fig. 10) and decrease in total nitrogen concentration (fig. 11B). Contributions from the Quiver River accounted for 99 percent of the increase in total nitrogen flux between sites 11 and 13, upstream and downstream of the Quiver River confluence (figs. 1 and 11A). In contrast to the Quiver River, total nitrogen 


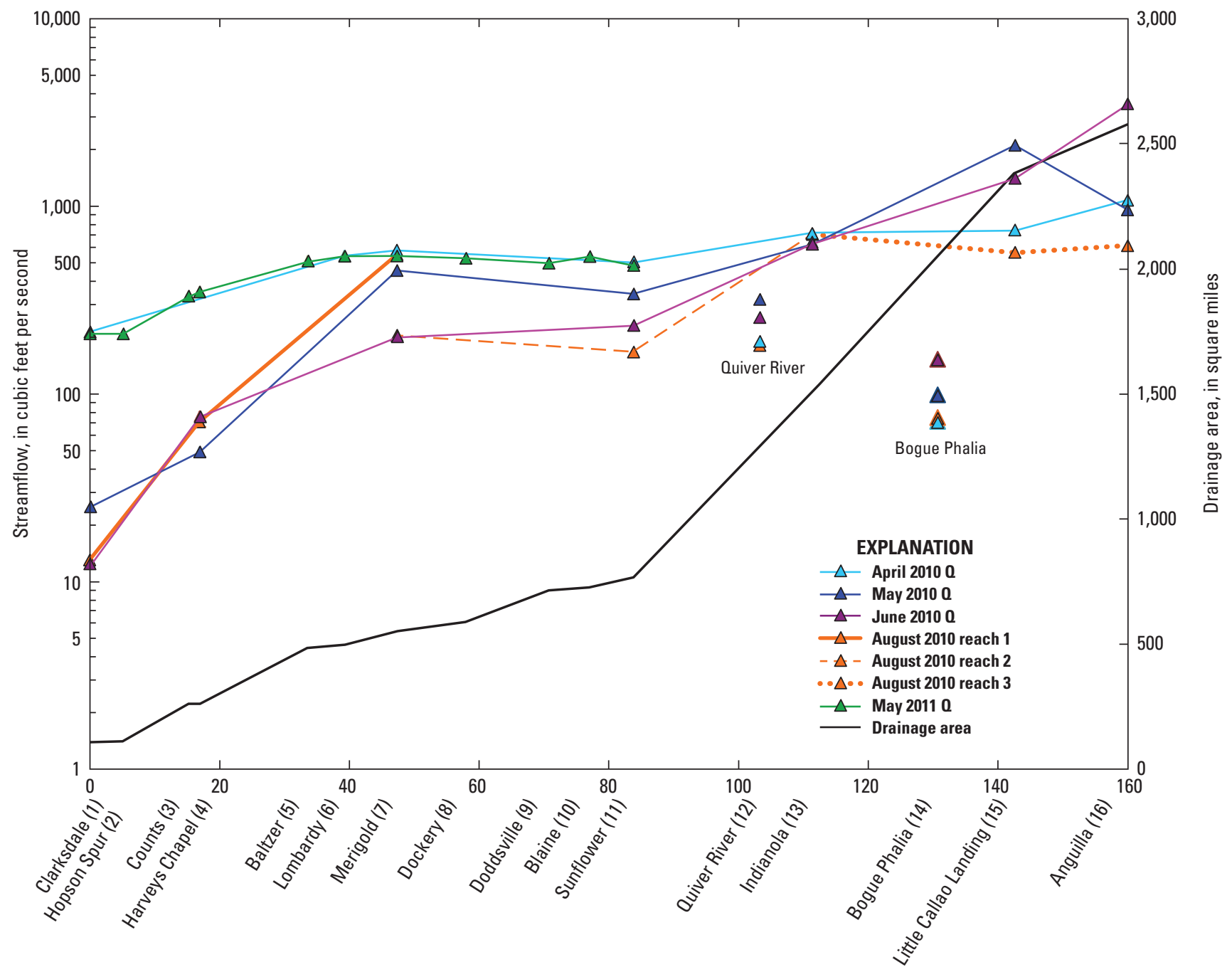

Distance from Clarksdale, in miles

Figure 10. Streamflow along the Big Sunflower River and the primary tributaries (Quiver River and Bogue Phalia) to the Big Sunflower River during each Lagrangian sampling event. Gaging stations are labeled along the $\mathrm{x}$-axis and the numbers in parenthesis denote the map identification numbers on figure 1 and in table 1.

flux decreased downstream between sites 13 and 15 , located upstream and downstream of the Bogue Phalia confluence as a result of a decrease in the concentration of total nitrogen and only a relatively small increase in streamflow (fig. 10).

Concentrations of total nitrogen generally decreased downstream from Clarksdale to Anguilla and ranged from 2.5 to $4.1 \mathrm{mg} / \mathrm{L}$ (fig. $11 B$ ). At Clarksdale, the majority of the total nitrogen was composed of organic nitrogen, although by the second sampling site (Lombardy), the concentration of total nitrogen was composed of almost equal parts organic nitrogen and nitrate plus nitrite. Concentrations of nitrate plus nitrite slightly increased downstream between Clarksdale and Anguilla and ranged from 0.8 to $1.6 \mathrm{mg} / \mathrm{L}$. Concentrations of ammonia decreased downstream throughout the sampled reach and ranged between 0.02 and $0.18 \mathrm{mg} / \mathrm{L}$.
The dominant form of nitrogen varied between Clarksdale and Anguilla; at Clarksdale, organic nitrogen composed 70 percent of the total nitrogen flux, whereas nitrate plus nitrite composed 17 percent and ammonia composed 12 percent (fig. 11A). At the second sampling site (Lombardy), the percentage of nitrate plus nitrite increased downstream to 43 percent of the total nitrogen flux, organic nitrogen decreased to 51 percent, and ammonia decreased to 6 percent. Downstream of the Lombardy site, the fluxes of nitrate plus nitrite and organic nitrogen remained approximately equal in proportion along the rest of the sampled reach (fig. 11). Contributions of total nitrogen from the Quiver River were dominated by organic nitrogen (63 percent), whereas contributions from the Bogue Phalia were composed of almost equal parts organic nitrogen (44 percent) and nitrate plus nitrate 

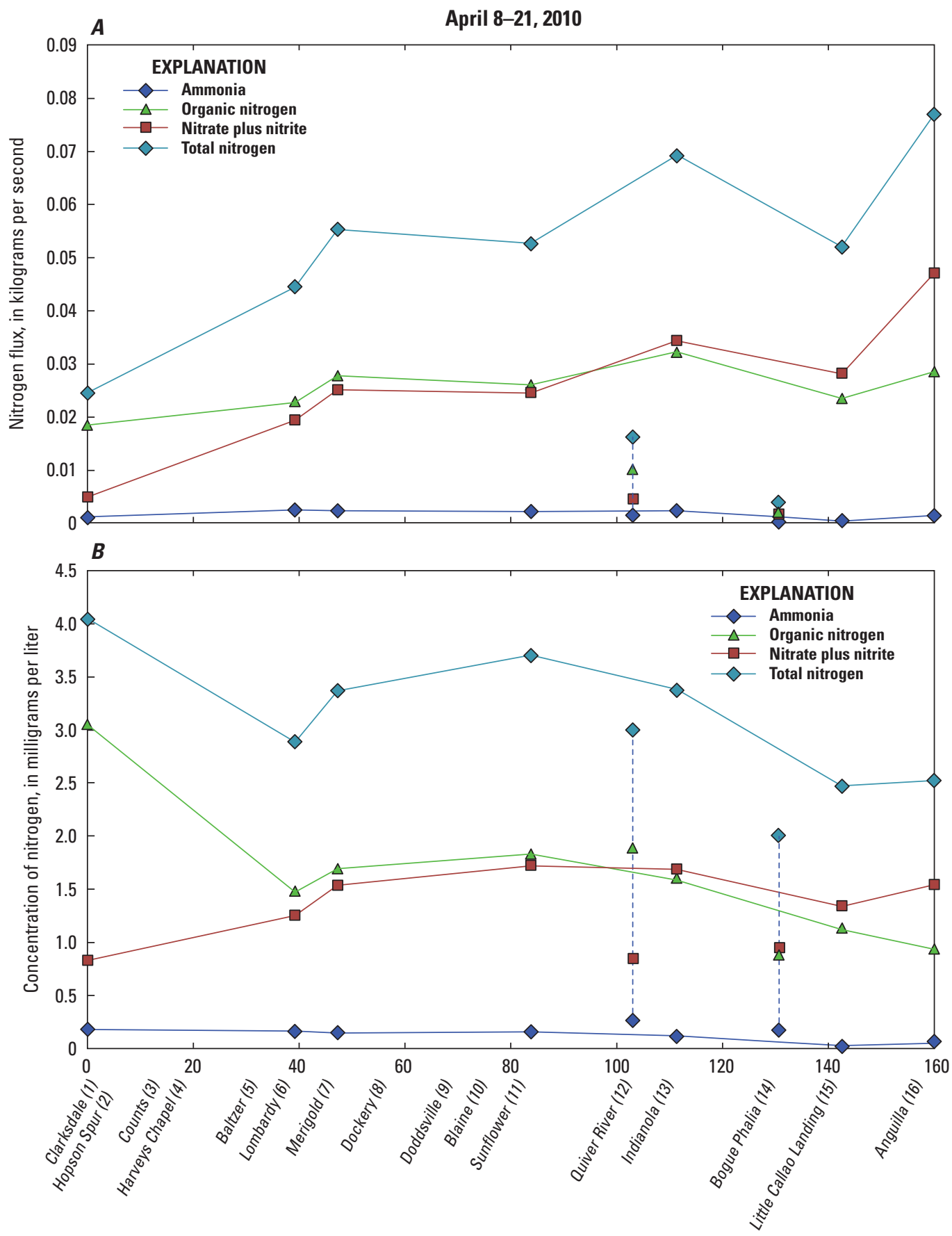

Distance from Clarksdale, in miles

Figure 11. $A$, Flux of nitrogen, and $B$, concentration of nitrogen as a function of distance from Clarksdale during the April 2010 Lagrangian sampling event. Gaging stations are labeled along the $x$-axis and the numbers in parenthesis denote the map identification numbers on figure 1 and in table 1.

(47 percent). Samples collected during the April Lagrangian sampling event were not analyzed for chloride.

\section{May 12-June 3, 2010}

Streamflow ranged between 24.9 and $2,100 \mathrm{ft}^{3} / \mathrm{s}$, generally increasing downstream except between Merigold and Sunflower and between Little Callao at mile 143 and Anguilla at mile 160 (fig. 10). Streamflow decreased 25 percent downstream between Merigold and Sunflower, from 455 to $340 \mathrm{ft}^{3} / \mathrm{s}$, because of a losing reach that has developed between these two stations in response to the shallow water table falling below the altitude of the streambed. Between Little Callao and Anguilla, streamflow decreased 55 percent downstream, from 2,100 to $952 \mathrm{ft}^{3} / \mathrm{s}$ (fig. 10), because of the 
closure of the Steele Bayou control structure downstream of Anguilla (fig. 1). Although the Steele Bayou control structure was closed throughout the sampling period, backwater effects were only observed at the Anguilla station. Contributions from the Quiver River accounted for 111 percent of the change in streamflow between sites 11 and 13 upstream and downstream of the Quiver River confluence (figs. 1 and 10). Contributions from the Bogue Phalia accounted for only 7 percent of the increase in streamflow between sites 13 and 15, upstream and downstream of the Bogue Phalia confluence. Between these two sites (13 and 15), streamflow increased downstream from 630 to $2,100 \mathrm{ft}^{3} / \mathrm{s}$ following several precipitation events, suggesting that overland runoff was responsible for the majority of streamflow increase rather than inflow from the Bogue Phalia.

The flux of total nitrogen and chloride increased downstream between Clarksdale and Anguilla, peaking at Little Callao Landing (site 15, figs. 1 and $12 A$ ) and then decreased by nearly 50 percent at Anguilla because of the large decrease in streamflow (fig. 10) and a small decrease in the concentration of total nitrogen and chloride. Fluxes of nitrogen and chloride increased and decreased correspondingly with the exception of nitrate plus nitrite flux between Merigold and Sunflower. Streamflow and fluxes of chloride, total nitrogen, organic nitrogen, and ammonia decreased between Merigold and Sunflower, whereas the flux of nitrate plus nitrite increased slightly (figs. 10 and 12A). Streamflow and nitrogen and chloride fluxes decreased between Little Callao and Anguilla because of backwater effects caused by the closure of the Steele Bayou control structure (fig. 10). Contributions from the Quiver River accounted for 88 percent of the increase in total nitrogen flux and 105 percent of the increase in chloride flux between sites 11 and 13 upstream and downstream of the Quiver River confluence (figs. 1 and 12A). Contributions from the Bogue Phalia accounted for 15 percent of the change in total nitrogen flux and 5 percent of the change in chloride flux between stations 13 and 15, upstream and downstream of the Bogue Phalia confluence.

Concentrations of total nitrogen ranged from 1.2 to $5.2 \mathrm{mg} / \mathrm{L}$ and generally increased downstream from Clarksdale to Anguilla, peaking at Sunflower (site 11, figs. 1 and 12B). At Clarksdale, the concentration of total nitrogen was composed of almost equal parts organic nitrogen and nitrate plus nitrite. Throughout the rest of the reach, nitrate plus nitrite was the dominant form of nitrogen in the stream. Concentrations of nitrate plus nitrite ranged from 0.6 to $3.4 \mathrm{mg} / \mathrm{L}$ and generally increased downstream between Clarksdale and Anguilla following a pattern similar to that of total nitrogen concentration (fig. 12B). Concentrations of ammonia generally decreased downstream throughout the sampled reach and ranged from 0.04 to $0.38 \mathrm{mg} / \mathrm{L}$. Concentrations of chloride varied between 4.9 and $20 \mathrm{mg} / \mathrm{L}$ throughout the reach.

At Clarksdale, organic nitrogen composed 46 percent of the total nitrogen flux, whereas nitrate plus nitrite composed 43 percent and ammonia composed 11 percent (fig. 12A). At Anguilla, the percentage of nitrate plus nitrite had increased to 71 percent, organic nitrogen decreased to 28 percent, and ammonia decreased to 1 percent. In comparison with the results from the April Lagrangian samples, nitrate plus nitrite was the dominant form of nitrogen throughout the majority of the sampling reach; in addition, as water moved downstream from Clarksdale to Anguilla, the percentage of total nitrogen composed of nitrate plus nitrite was consistently larger than observed in April, with nitrate plus nitrite composing the majority of the total nitrogen flux.

\section{June 15-July 1, 2010}

Streamflow ranged from 12.2 to $3,500 \mathrm{ft}^{3} / \mathrm{s}$, increasing with drainage area throughout the sampling event (fig. 10). June was the only Lagrangian sampling event in which streamflow did not decrease between Merigold and Sunflower. One possible explanation for this lack of decrease in streamflow could be augmentation by irrigation return flow. Contributions from the Quiver River accounted for 66 percent of the change in streamflow between sites 11 and 13 upstream and downstream of the Quiver River confluence (figs. 1 and 10). Contributions from the Bogue Phalia accounted for 19 percent of the change in streamflow between sites 13 and 15 upstream and downstream of the Bogue Phalia confluence. Precipitation events occurred throughout the sampling period and, therefore, overland runoff probably accounted for the majority of streamflow increases, in addition to the inflows from the Quiver River and Bogue Phalia.

The flux of total nitrogen and chloride increased correspondingly from Clarksdale to Anguilla (fig. 13A). The Steele Bayou control structure was opened a day before the Anguilla site was sampled, allowing water to flow from the Big Sunflower River into the Yazoo and Mississippi Rivers. As a result, fluxes of nitrogen and chloride more than doubled between Little Callao and Anguilla. Contributions from the Quiver River accounted for 77 percent of the increase in both total nitrogen and chloride flux between sites 11 and 13, upstream and downstream of the Quiver River confluence (figs. 1 and $13 A$ ). Contributions from the Bogue Phalia accounted for 44 percent of the change in total nitrogen flux and 13 percent of the change in chloride flux between sites 13 and 15, upstream and downstream of the Bogue Phalia confluence.

Concentrations of total nitrogen ranged from 1.4 to $3.3 \mathrm{mg} / \mathrm{L}$ and generally decreased downstream between Clarksdale and Anguilla, peaking at Harvey's Chapel (site 4, figs. 1 and 13B). At Clarksdale, the majority of the total nitrogen concentration was composed of organic nitrogen, but at Harvey's Chapel, the concentration of total nitrogen was composed of almost equal parts organic nitrogen and nitrate plus nitrite. Concentrations of nitrate plus nitrite ranged from 0.4 to $1.5 \mathrm{mg} / \mathrm{L}$ and generally increased downstream between Clarksdale and Anguilla, following a pattern similar to that of total nitrogen concentration (fig. 13B). Concentrations of ammonia decreased downstream throughout the sampled reach and ranged from 0.01 to $0.47 \mathrm{mg} / \mathrm{L}$. Concentrations of chloride ranged from 6.7 to $17 \mathrm{mg} / \mathrm{L}$ and generally increased from Clarksdale to Anguilla. 

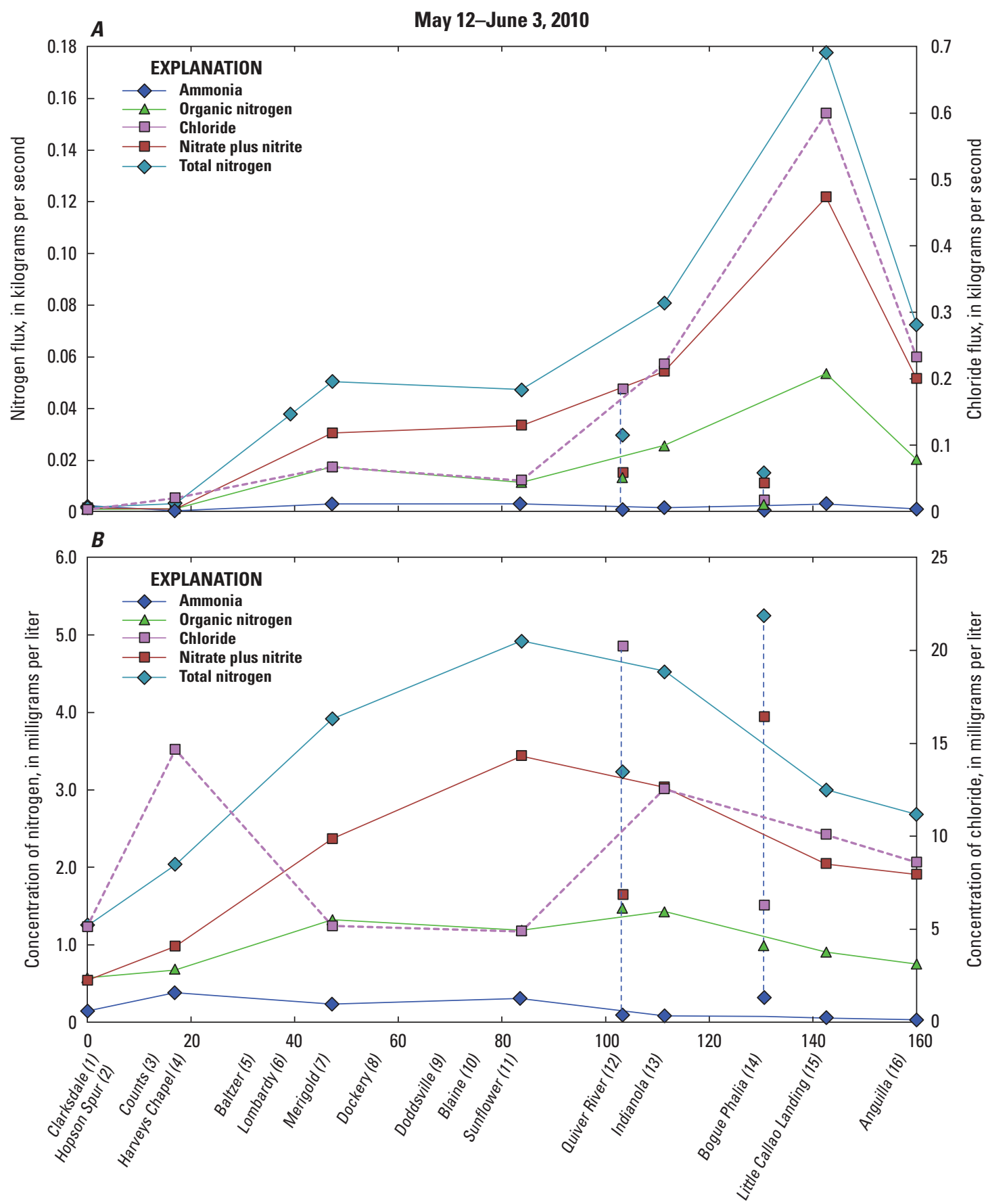

Distance from Clarksdale, in miles

Figure 12. $A$, Flux of nitrogen and chloride, and $B$, concentration of nitrogen and chloride as a function of distance from Clarksdale during the May 2010 Lagrangian sampling event. Gaging stations are labeled along the $x$-axis and the numbers in parenthesis denote the map identification numbers on figure 1 and in table 1.

At Clarksdale, organic nitrogen composed 60 percent of the total nitrogen flux, whereas nitrate plus nitrite composed 23 percent and ammonia composed 18 percent. The amount of nitrate plus nitrite in the stream increased from 23 to 52 percent of the total nitrogen flux between Clarksdale and Sunflower and then decreased to 38 percent between Sunflower and Anguilla. At Anguilla, organic nitrogen composed 51 percent of the total nitrogen flux and ammonia composed 11 percent.
August 23-30, 2010

Because of logistical constraints, three Lagrangian sampling events were conducted concurrently on three reaches between Clarksdale and Anguilla: one between Clarksdale and Merigold (Reach 1), a second between Merigold and Indianola (Reach 2), and a third between Indianola and Anguilla (Reach 3). Streamflow increased from 13.1 to $556 \mathrm{ft}^{3} / \mathrm{s}$ within 

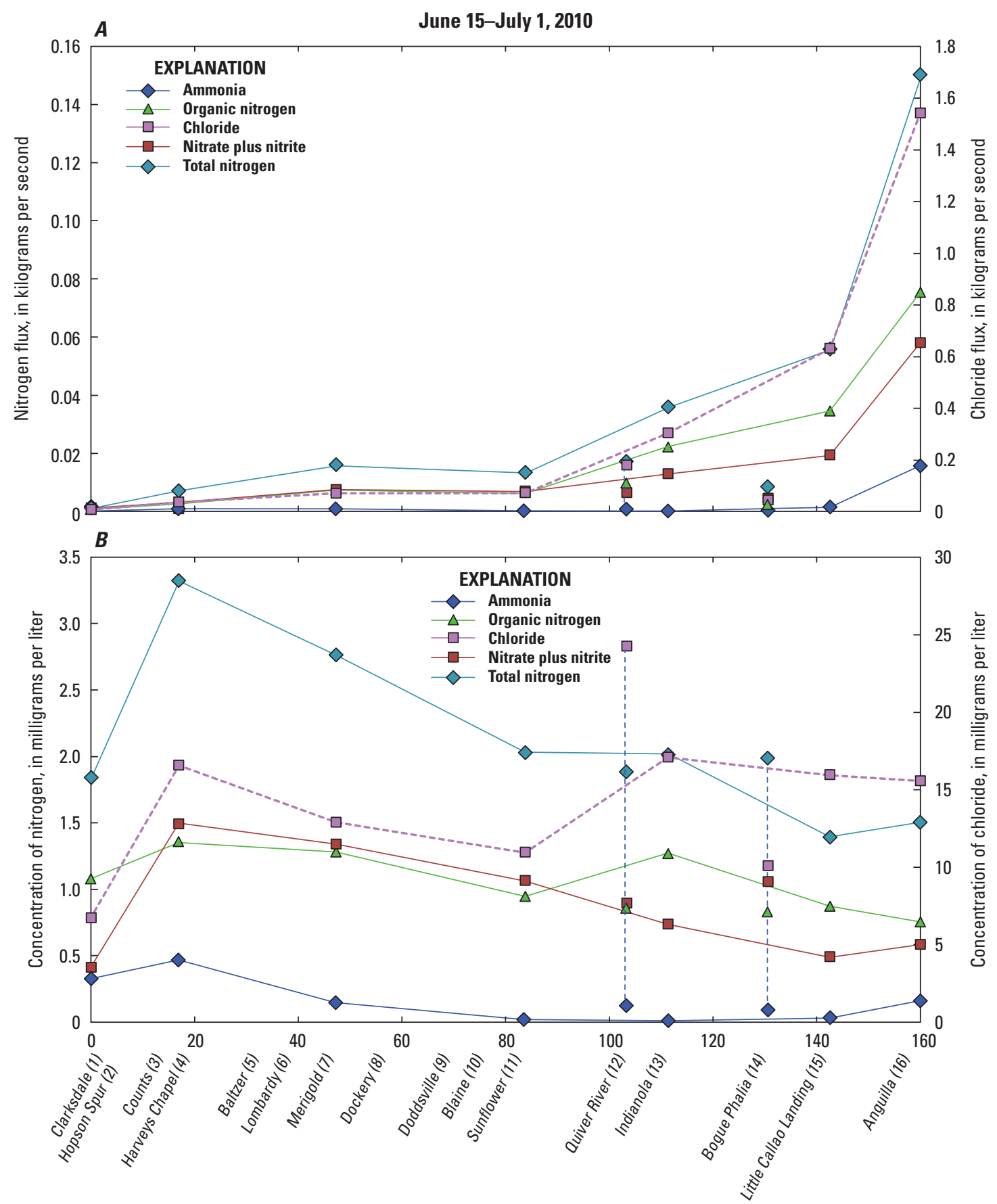

Distance from Clarksdale, in miles

Figure 13. A, Flux of nitrogen and chloride, and $B$, concentration of nitrogen and chloride as a function of distance from Clarksdale during the June 2010 Lagrangian sampling event. Gaging stations are labeled along the $x$-axis and the number in parenthesis denotes the map identification number on figure 1 and in table 1.

Reach 1, increased from 207 to $700 \mathrm{ft}^{3} / \mathrm{s}$ within Reach 2, and decreased from 707 to $618 \mathrm{ft}^{3} / \mathrm{s}$ within Reach 3 (fig. 10).

Fluxes of nitrogen were 1 to 2 orders of magnitude lower than those observed during all other Lagrangian sampling events, whereas streamflow was generally within the range observed in other Lagrangian sampling events. The flux of total nitrogen increased within Reaches 1 and 2 and decreased within Reach 3, with organic nitrogen flux composing the majority of the total nitrogen flux within all three reaches (fig. 14A). Fluxes of chloride increased and decreased with total nitrogen fluxes throughout each reach. However, fluxes of nitrate plus nitrite were inversely related to fluxes of chloride between Sunflower and Indianola within Reach 2, with fluxes of nitrate plus nitrite decreasing as streamflow and chloride flux increased. This relation is the result of inflow from the Quiver River containing relatively high concentrations of 

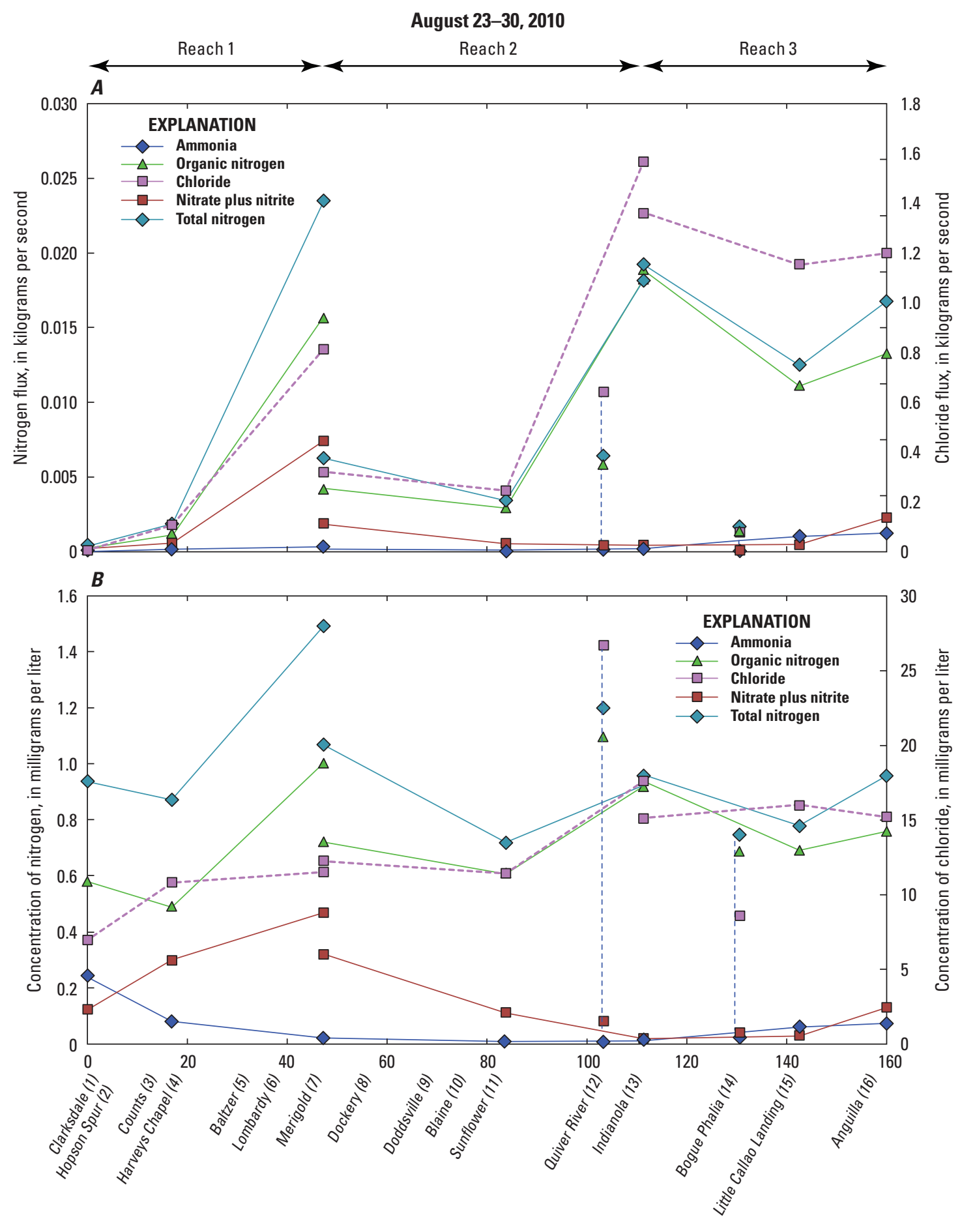

Distance from Clarksdale, in miles

Figure 14. $A$, Flux of nitrogen and chloride, and $B$, concentration of nitrogen and chloride as a function of distance from Clarksdale during the August 2010 Lagrangian sampling event. Gaging stations are labeled along the $\mathrm{x}$-axis and the numbers in parenthesis denote the map identification numbers on figure 1 and in table 1.

chloride and low concentrations of nitrate plus nitrite. Additionally, the overall decrease in both the flux and concentration of nitrate plus nitrite throughout Reach 2 indicates a loss of nitrate plus nitrite potentially related to either uptake or denitrification. Fluxes and concentrations of nitrate plus nitrite increased slightly within Reach 3 and showed no net loss between any sites within the reach. Contributions from the Quiver River accounted for 43 and 89 percent of the increase in total nitrogen and chloride flux, respectively, between sites 11 and 13 upstream and downstream of the Quiver River confluence. Contributions from the Bogue Phalia had a negligible effect on both total nitrogen and chloride flux between 
sites 13 and 15, upstream and downstream of the Bogue Phalia confluence (figs. 1 and 14A). Streamflow decreased between these two stations and resulted in a decrease in the fluxes of total nitrogen and chloride despite the small fluxes of total nitrogen and chloride entering the Big Sunflower River from the Bogue Phalia. This result could be due to timing errors associated with either under- or over-predicting the transit time of the tagged water parcel. The Steele Bayou control structure was open throughout the August 2010 sample period and, therefore, did not affect streamflow.

Concentrations of total nitrogen ranged from 0.87 to $1.5 \mathrm{mg} / \mathrm{L}$ throughout Reach 1 , from 0.72 to almost $1.1 \mathrm{mg} / \mathrm{L}$ throughout Reach 2, and from 0.78 to $0.96 \mathrm{mg} / \mathrm{L}$ throughout Reach 3, generally decreasing between Clarksdale and Anguilla, with the highest concentration occurring at Merigold at the end of Reach 1 (site 7, figs. 1 and 14B). The majority of the total nitrogen concentration was composed of organic nitrogen throughout all three reaches because of the relatively low concentrations of nitrate plus nitrite as compared to other sampling events. Concentrations of nitrate plus nitrite ranged from 0.12 to $0.47 \mathrm{mg} / \mathrm{L}$ throughout Reach 1 , from 0.02 to $0.32 \mathrm{mg} / \mathrm{L}$ throughout Reach 2, and from 0.02 to $0.13 \mathrm{mg} / \mathrm{L}$ throughout Reach 3, generally decreasing between Clarksdale and Anguilla (fig. 14B). Concentrations of ammonia ranged from 0.01 to $0.24 \mathrm{mg} / \mathrm{L}$, and decreased throughout Reaches 1 and 2 while increasing slightly throughout Reach 3 . Concentrations of chloride ranged between 6.9 and $18 \mathrm{mg} / \mathrm{L}$, generally increasing throughout Reaches 1 and 2 while remaining relatively constant throughout Reach 3 .

\section{May 16-20, 2011}

Streamflow ranged between 209 to $543 \mathrm{ft}^{3} / \mathrm{s}$ throughout the reach, generally increasing as drainage area increased, with the exception of three reaches where small losses of streamflow were measured. Specifically, streamflow decreased 6 percent between Merigold and Dockery, from 543 to $529 \mathrm{ft}^{3} / \mathrm{s}$, decreased 6 percent between Dockery and Doddsville, from 529 to $498 \mathrm{ft}^{3} / \mathrm{s}$, and decreased 10 percent between Blaine and Sunflower, from 539 to $485 \mathrm{ft}^{3} / \mathrm{s}$ (fig. 10).

The flux of total nitrogen increased between Clarksdale and Sunflower, with organic nitrogen composing the majority of total nitrogen flux throughout most of the reach (fig. 15A). At Clarksdale, organic nitrogen composed 56 percent of the total nitrogen flux, whereas nitrate plus nitrite composed 34 percent and ammonia composed 8 percent. At Sunflower, the percentage of nitrate plus nitrite had increased to 55 percent, organic nitrogen had decreased to 42 percent, and ammonia had decreased to 3 percent. Streamflow and chloride flux increased and decreased monotonically within the reaches from Baltzer to Merigold, Dockery to Doddsville, and Blaine to Sunflower, whereas fluxes of nitrate plus nitrite within these reaches were inversely related to streamflow and chloride flux. Although the Steele Bayou control structure was closed throughout the May 2011 sampling event, there was no evidence that backwater conditions affected the sampled reach.
Concentrations of total nitrogen ranged from 1.4 to $2.0 \mathrm{mg} / \mathrm{L}$, peaking at Baltzer (site 5, figs. 1 and 15). Between Clarksdale and Baltzer, the majority of the total nitrogen concentration was composed of organic nitrogen. From Baltzer to Sunflower, the concentration of total nitrogen was composed of almost equal parts organic nitrogen and nitrate plus nitrite. Concentrations of nitrate plus nitrite ranged from 0.6 to $1.0 \mathrm{mg} / \mathrm{L}$ and generally increased between Clarksdale and Sunflower (fig. 15B). Concentrations of ammonia decreased throughout the sampled reach and ranged from 0.03 to $0.44 \mathrm{mg} / \mathrm{L}$. Concentrations of chloride ranged from 3.3 to $7.0 \mathrm{mg} / \mathrm{L}$ and generally increased between Clarksdale and Sunflower (fig. 15B).

\section{Conservation of Nitrogen in the Big Sunflower River}

Several methods were employed to assess the fate of nitrogen, and specifically, if any net loss of nitrogen occurs along the Big Sunflower River. Net loss of nitrogen was assessed by comparing total nitrogen flux from the Lagrangian sampling events to chloride flux data, drainage area, and predicted total nitrogen flux results from two previously published national and regional SPARROW models, which assume relatively conservative transport within the main channel of the Big Sunflower River (fig. 16). The assumption in the chloride comparison is that any net loss of nitrogen occurring within the Big Sunflower River would result in a measurable decrease in the mass or flux of total nitrogen relative to chloride (a conservative constituent), drainage area, and (or) predicted total nitrogen fluxes.

Concentrations and fluxes of nitrogen were compared with the concentration and flux of chloride, which is transported conservatively, in order to assess any net loss of nitrogen over time along the sampled reach of the Big Sunflower River (Battaglin and others, 2001).

Instantaneous fluxes of total nitrogen and chloride were positively correlated (coefficient of determination $\left(\mathrm{R}^{2}\right)=0.56$, $\rho=1.87 \times 10^{-07}$ ) implying no net loss of total nitrogen relative to chloride (fig. 16A). With the exception of three reaches, total nitrogen flux increased with drainage area along the sampled reach of the Big Sunflower River, indicating that, along most of the Big Sunflower River, no net loss of total nitrogen occurs relative to drainage area. The flux of total nitrogen decreased relative to drainage area between Merigold and Sunflower, Indianola and Little Callao, and Little Callao and Anguilla (fig. 16B). Similarly, with the exception of these three reaches (Merigold and Sunflower, Indianola and Little Callao, and Little Callao and Anguilla), measured total nitrogen fluxes from each of the Lagrangian sampling events generally follow predicted fluxes from both the national- and regional-level SPARROW models (fig. 16C).

Between Merigold and Sunflower, a decrease in total nitrogen flux was observed during four of the five Lagrangian sampling events; on average, streamflow decreased by 

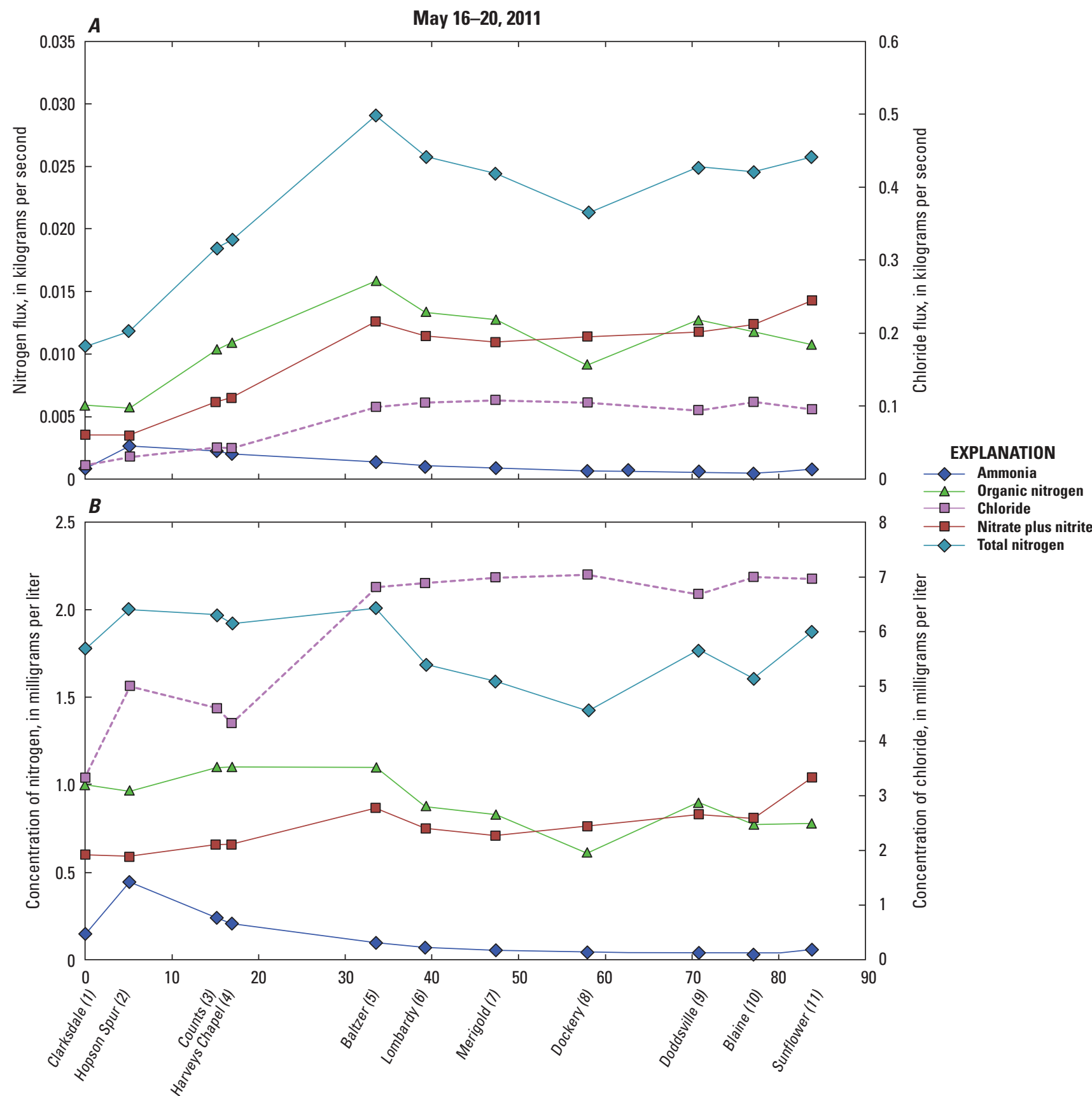

Distance from Clarksdale, in miles

Figure 15. $A$, Flux of nitrogen and chloride, and $B$, concentration of nitrogen and chloride as a function of distance from Clarksdale during the May 2011 Lagrangian sampling event. Gaging stations are labeled along the $x$-axis and the numbers in parenthesis denote the map identification numbers on figure 1 and in table 1.

11 percent (fig. 10) and total nitrogen flux decreased by 13 percent (fig. 16B). These decreases in both streamflow and the flux of nitrogen in the stream are due to extensive groundwater withdrawals, resulting in a cone of depression along this section of the Big Sunflower River (Barlow and Clark, 2011). Declining groundwater levels have resulted in a groundwater table that is lower than the streambed, and therefore, the stream is generally losing throughout this reach. Because the losses in nitrogen are coincident with streamflow losses, nitrogen losses throughout this reach are probably due to the transport of water through the streambed rather than instream denitrification or other processes. This assumption is further validated by consistent losses in chloride flux (figs. 11-15) in addition to streamflow losses (fig. 10) occurring throughout this reach. Streambeds represent the interface between surface-water and groundwater processes with resulting dynamic biogeochemical properties. A previous study conducted by Barlow and Coupe (2012) in the Bogue Phalia Basin, a contributing basin to the Big Sunflower River, showed that conditions in the streambed and underlying aquifer are conducive for denitrification, based on an estimated 

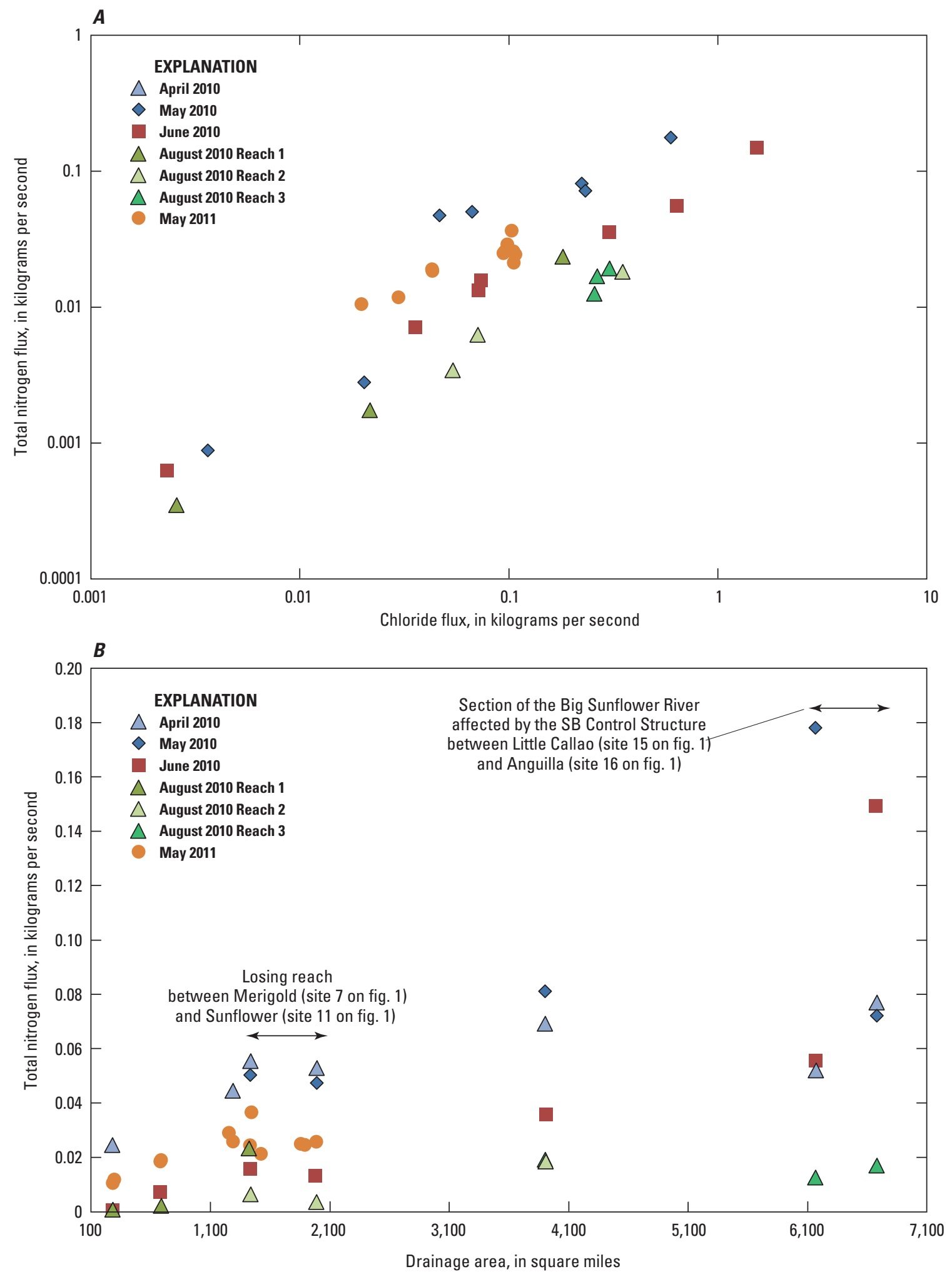

Figure 16. Instantaneous flux of total nitrogen relative to $A$, the instantaneous flux of chloride, $B$, drainage area, and $C$, predicted instantaneous total nitrogen fluxes from SPARROW models. SB is Steele Bayou drainage control structure. 


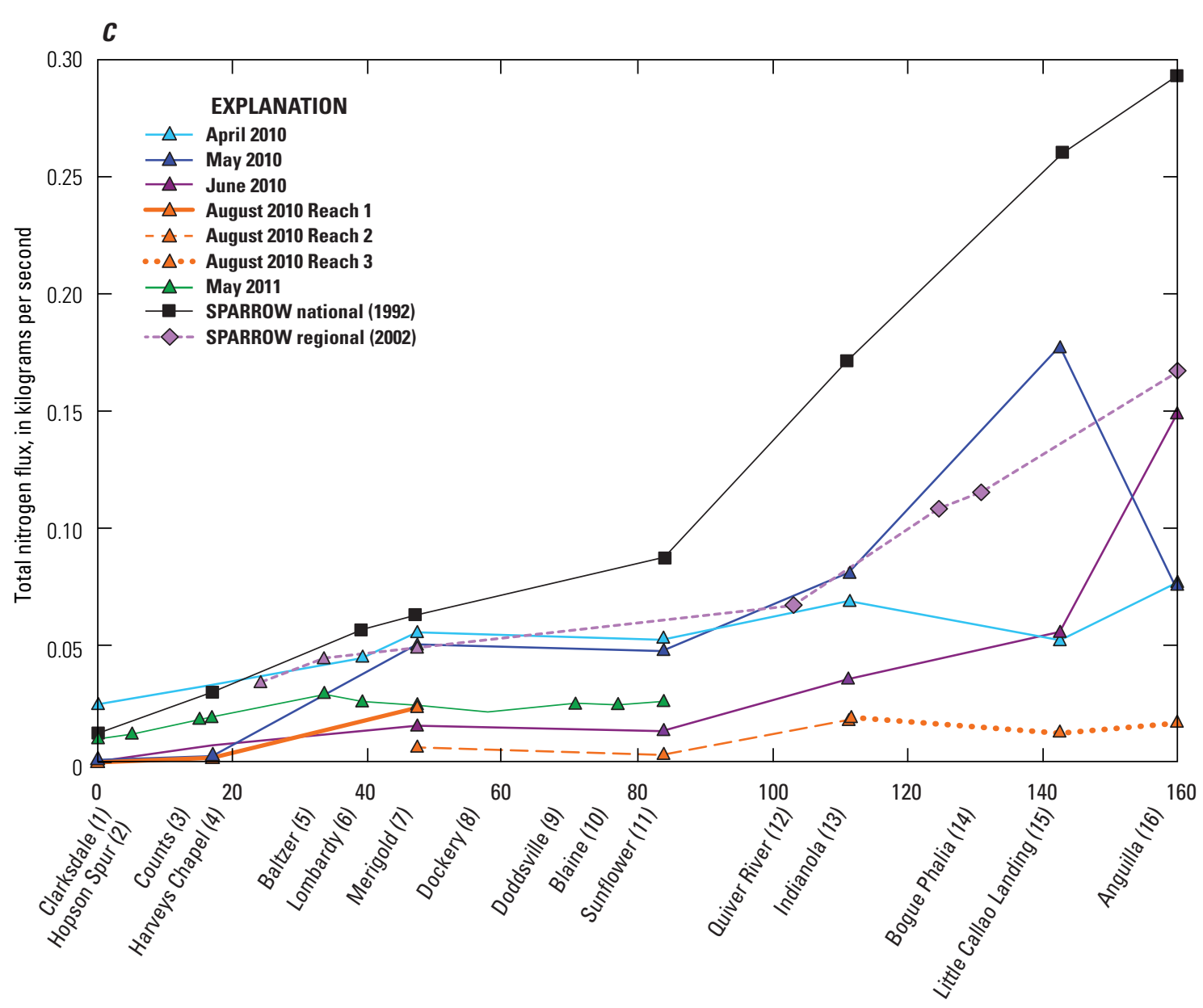

Distance from Clarksdale, in miles



Figure 16. Graphs showing the instantaneous flux of total nitrogen relative to $A$, the instantaneous flux of chloride, $B$, drainage area, and $C$, predicted instantaneous total nitrogen fluxes from SPARROW models. SB is Steele Bayou drainage control structure. Gaging stations are labeled along the $x$-axis and the numbers in parenthesis denote the map identification numbers on figure 1 and in table 1.-Continued

average streambed denitrification rate of 11,614 micromoles nitrogen per square meter per hectare $\left(\mu \mathrm{mol} \mathrm{N} \mathrm{m} \mathrm{N}^{-2} \mathrm{~h}^{-1}\right)$. This finding is an order of magnitude larger than other published values (Böhlke and others, 2009). Therefore, losing reaches of the Big Sunflower River, such as the reach between Merigold and Sunflower, may transport nitrogen through the streambed and also have the potential to remove nitrogen in the form of nitrate plus nitrite through denitrification.

In two Lagrangian sampling events, fluxes of total nitrogen were found to decrease relative to drainage area in the reach between Indianola and Little Callao (fig. 16B). The first of these decreases occurred in the April 2010 event and was concurrent with a small increase in streamflow (fig. 10) and decrease in the concentration of all forms of nitrogen (fig. 11B). Samples collected during this event were not analyzed for chloride so it is not possible to compare the flux of nitrogen to the flux of chloride for further interpretation. The second event in August 2010 was concurrent with a small decrease in streamflow (fig. 10) and decrease in total nitrogen concentration (fig. 14B). Organic nitrogen made up the majority of nitrogen throughout the August 2010 Lagrangian sampling event, and the decrease in total nitrogen concentration was because of a decrease in organic nitrogen concentration; concentrations of nitrate plus nitrite and ammonia increased between Indianola and Little Callao. The flux of chloride also decreased between Indianola and Little Callao during this time period. The combination of these results, decreasing flux of total nitrogen and chloride, decreasing streamflow, and increasing concentration and flux of nitrate plus nitrite do not directly suggest denitrification occurring within the stream channel. However, the decrease in both concentration and flux of organic nitrogen and the concurrent increase in concentration and flux of ammonia and nitrate plus nitrite could suggest mineralization, or ammonification. 
Fluxes of total nitrogen also decreased, in one instance, relative to drainage area between Little Callao and Anguilla, near the confluence of the Big Sunflower River with the Yazoo River (fig. 16B). This section of the Big Sunflower River is affected by the operation of the Steele Bayou control structure. During periods when the control structure is closed, backwater effects generally cause a decrease in streamflow throughout this section, resulting in a decrease in the flux of total nitrogen and at least a temporary delay in the transport of nitrogen out of the basin. The control structure was closed during parts of all Lagrangian sampling events except for August 2010. During the April and June 2010 Lagrangian sampling events, the control structure was opened after the sampling of Little Callao, resulting in an increase in streamflow and total nitrogen flux between Little Callao and Anguilla. During the May 2010 and May 2011 Lagrangian sampling events, the control structure was closed throughout the entire sampling period. Although the May 2011 Lagrangian sampling events did not include the Little Callao to Anguilla reach, the May 2010 Lagrangian data indicate a large decrease in streamflow and total nitrogen and chloride fluxes caused by the closure of the Steele Bayou control structure (figs. 10 and 12A).

Closure of the Steele Bayou control structure delays transport of nitrogen and potentially aids in its removal by creating hypoxic conditions conducive to denitrification. When the control structure is closed, the lower reach of the Big Sunflower River experiences backwater effects that decrease streamflow and the flux of total nitrogen. The extent of backwater effects on the transport of nitrogen is related to streamflow rates and nitrogen concentrations in the Big Sunflower River and the length of time the control structure is closed. By decreasing flow velocities, backwater can result in a clinograde oxygen profile in which oxygen decreases with depth. A clinograde develops when a lack of vertical circulation inhibits the replenishment of oxygen consumed at depth (Wetzel, 2001). This assumes that the body of water has nutrients and organic matter for productivity. During June of the 2010 water year, two depth-integrated samples were collected, and dissolved oxygen was measured throughout the water column at a USGS site (station 323045090484300) on the Little Sunflower Diversion Canal 6 mi upstream of the Steele Bayou control structure and 46 mi downstream from the Big Sunflower near Anguilla site. Samples and measurements of dissolved oxygen were collected before the control structure was closed and 8 days after it was closed (fig. 17). When the control structure was open, the oxygen profile was relatively uniform and the concentration of nitrate plus nitrite was $1.02 \mathrm{mg} / \mathrm{L}$; however, 8 days after the control structure was closed, a distinct clinograde oxygen profile was measured and the concentration of nitrate plus nitrite was $0.42 \mathrm{mg} / \mathrm{L}$. Although a more extensive study would be needed to document the effects of the control structure on nitrate-plus-nitrite concentrations, these data suggest the potential for denitrification during periods when the control structure is closed. Within the reach sampled as part of this study, however, there was no evidence of a net loss of nitrogen caused by closure of the Steele Bayou control structure, only a decrease in nitrogen flux caused by a decrease in streamflow.
Results from this study were used to assess the fate of nitrogen and, specifically, whether or not a net loss of nitrogen occurs within the Big Sunflower River. Net loss of nitrogen was assessed by comparing total nitrogen data from the Lagrangian sampling events to chloride, drainage area, and predicted total nitrogen flux results from previously published national and regional SPARROW models, which assume relatively conservative transport within the Big Sunflower River. Results from each method indicated the relatively conservative transport of nitrogen within the $160 \mathrm{mi}$ between Clarksdale and Anguilla, providing further validation of the SPARROW models and the assumption that nitrogen transport is relatively conservative at the scale of the Big Sunflower River Basin. However, potential nitrogen losses include transport and potential transformation of nitrogen through the streambed and sequestration and potential transformation of nitrogen above the drainage control structures downstream of Anguilla.

\section{Summary and Conclusions}

Understanding how nutrients are transported in and downstream from the Big Sunflower River Basin, an agricultural area subject to large annual inputs of nitrogen from agriculture, is key to quantifying their eutrophying effects on the Gulf of Mexico. Recent results from two Spatially Referenced Regressions on Watershed attributes (SPARROW models), which include the Big Sunflower River, indicate minimal losses of nitrogen in stream reaches typical of the main channels of major river systems. If SPARROW assumptions of relatively conservative transport of nitrogen are correct and surface-water losses through the bed of the Big Sunflower River are negligible, then options for managing nutrient loads to the Gulf of Mexico may be limited. Simply put, if every pound of nitrogen entering the Delta is eventually delivered to the Gulf, then the only effective nutrient management option in the Delta is to reduce inputs. If on the other hand it can be shown that processes within river channels of the Mississippi Delta act to reduce the mass of nitrogen in transport, other hydrologic approaches may be designed to further limit nitrogen transport. Direct validation of existing SPARROW models for the Delta is a first step in assessing the assumptions underlying those models.

The U.S. Geological Survey, in cooperation with the U.S. Army Corps of Engineers, initiated a study in 2010 to characterize the occurrence and transport of nitrogen in the Big Sunflower River Basin. The specific objective was to validate the results from the two SPARROW models for the Big Sunflower River Basin while providing further information about nitrogen transport within the Big Sunflower River Basin, which contributes much of the water discharging from the Yazoo River Basin to the Mississippi River. Results from this study were used to assess the fate of nitrogen and, specifically, whether or not a net loss of nitrogen occurs within the Big Sunflower River. Net loss of nitrogen was assessed by comparing total nitrogen data from Lagrangian sampling events to chloride, drainage area, and predicted total nitrogen flux results from previously published 


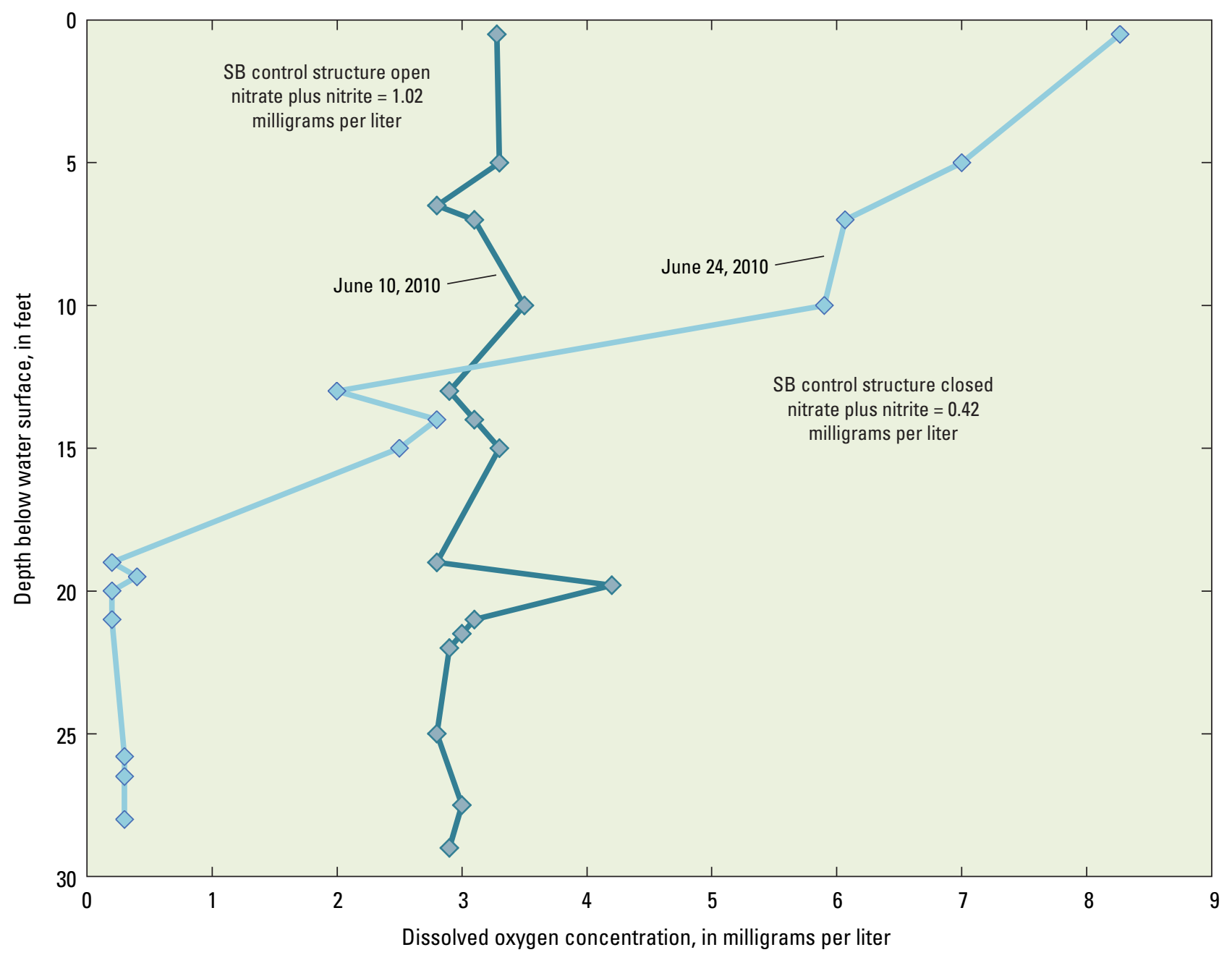

Figure 17. Variability in concentrations of dissolved oxygen with depth and the depth composite concentrations of nitrate plus nitrite at the Little Diversion Canal near Redwing, Miss., site before and after the closure of the Steele Bayou (SB) drainage control structure.

national and regional SPARROW models, which assume relatively conservative transport within the Big Sunflower River.

Results from each method indicate relatively conservative transport of nitrogen within the 160 miles between Clarksdale and Anguilla, providing further validation of the SPARROW models. Furthermore, these results suggest relatively conservative transport from the Big Sunflower River to the Gulf of Mexico and, therefore, imply a fairly close association of nutrient application and export from the Big Sunflower River Basin to the Mississippi River. However, within the Big Sunflower River Basin, two potential nitrogen sinks were identified and include the transport and potential transformation of nitrogen through the streambed and the sequestration and potential transformation of nitrogen above the drainage control structures downstream of Anguilla. By coupling these potential loss mechanisms with nitrogen transport dynamics, it may be possible to further reduce the amount of nitrogen leaving the Big Sunflower River Basin and ultimately arriving at the Gulf of Mexico.

\section{References Cited}

Alexander, R.B., Smith, R.A., Schwarz, G.E., Boyer, E.W., Nolan, J.V., and Brakebill, J.W., 2008, Differences in phosphorus and nitrogen delivery to the Gulf of Mexico from the Mississippi River Basin: Environmental Science and Technology, v. 42, no. 3, p. 822-830. (Also available at http://dx.doi.org/10.1021/es0716103.)

Arthur, J.K., 2001, Hydrogeology, model description, and flow analysis of the Mississippi River alluvial aquifer in northwestern Mississippi: U.S. Geological Survey WaterResources Investigations Report 01-4035, 47 p.

Barlow, J.R.B., and Clark, B.R., 2011, Simulation of water-use conservation scenarios for the Mississippi Delta using an existing regional groundwater flow model: U.S. Geological Survey Scientific Investigations Report 2011-5019, 14 p. 
Barlow, J.R.B., and Coupe, R.H., 2012, Groundwater and surface-water exchange and resulting nitrate dynamics in the Bogue Phalia basin in northwestern Mississippi: Journal of Environmental Quality, v. 41, no. 1, p. 155-169. (Also available at $h t t p: / / d x$.doi.org/10.2134/jeq2011.0087.)

Battaglin, W.A., Kendall, C., Chang, C.C.Y., Silva, S.R., and Campbell, D.H., 2001, Chemical and isotopic evidence of nitrogen transformation in the Mississippi River, 1997-98: Hydrological Processes, v. 15, no. 7, p. 1285-1300. (Also available at http://dx.doi.org/10.1002/hyp.214.)

Böhlke, J.K., Antweiler, R., Harvey, J., Laursen, A., Smith, L., Smith, R., and Voytek, M., 2009, Multi-scale measurements and modeling of denitrification in streams with varying flow and nitrate concentration in the upper Mississippi River Basin, USA: Biogeochemistry, v. 93, no. 1, p. 117-141. (Also available at $h t t p: / / d x$.doi.org/10.1007/s10533-0089282-8.)

Coupe, R., Goolsby, D., Battaglin, W., Böhlke, J., McMahon, P., and Kendall, C., 2013, Transport of nitrate in the Mississippi River in July-August 1999: Annals of Environmental Science, v. 7, no. 1. Accessed June 2012, at http://iris.lib. neu.edu/aes/vol7/iss 1/3.

Delwiche, C.C., and Bryan, B.A., 1976, Denitrification: Annual Review of Microbiology, v. 30, no. 1, p. 241-262. (Also available at $h t t p: / / d x$.doi.org/10.1146/annurev. mi.30.100176.001325.)

Economic Research Service, U.S. Department of Agriculture, 2013, The economics of food, farming, natural resources, and rural America - State fact sheets-Mississippi, accessed July 25,2013, at $h t t p: / / w w w . e r s . u s d a . g o v / d a t a-p r o d u c t s /$ state-fact-sheets/state-data.aspx?StateFIPS=28\&StateNam $e=$ Mississippi\#.

Fishman, M.J., ed., 1993, Methods of analysis by the U.S. Geological Survey National Water Quality LaboratoryDetermination of inorganic and organic constituents in water and fluvial sediments: U.S. Geological Survey OpenFile Report 93-125, $217 \mathrm{p}$.

Fishman, M.J., and Friedman, L.C., 1989, Methods for determination of inorganic substances in water and fluvial sediments: U.S. Geological Survey Techniques of Water Resources Investigations, book 5, chap. A1, 545 p., accessed November 1, 2010, at http://pubs.water.usgs.gov/TWRI5A1/.

Galloway, J.N., Aber, J.D., Erisman, J.W., Seitzinger, S.P., Howarth, R.W., Cowling, E.B., and Cosby, B.J., 2003, The nitrogen cascade: BioScience, v. 53, no. 4, p. 341-356.

Goolsby, D.A., and Battaglin, W.A., 2001, Long-term changes in concentrations and flux of nitrogen in the Mississippi River Basin, USA: Hydrological Processes, v. 15, no. 7, p. 1209-1226. (Also available at http://dx.doi.org/10.1002/ hyp.210.)
Helsel, D.R., Hirsch, R.M., 1992, Statistical methods in water resources (paper/diskette ed.): Elsevier Science.

Mississippi State University Department of Agricultural Economics, 2009, Delta 2010 planning budgets: Budget Report 2009-06, 185 p.

Moody, J.A., 1993, Evaluation of the Lagrangian scheme for sampling the Mississippi River during 1987-90: U.S. Geological Survey Water-Resources Investigations Report 93-4042, $31 \mathrm{p}$.

Rabalais, N.N., and Turner, R.E., 2001, Hypoxia in the northern Gulf of Mexico-Description, causes and change: Coastal and Estuarine Studies, v. 58, no. 1-36. (Also available at $h t t p: / / d x . d o i . o r g / 10.1029 / C E 058 p 0001$.

Rabalais, N.N., Turner, R.E., JustiĆ, D., Dortch, Q., Wiseman, W., and Sen Gupta, B., 1996, Nutrient changes in the Mississippi River and system responses on the adjacent continental shelf: Estuaries and Coasts, v. 19, no. 2, p. 386-407. (Also available at $h t t p: / / d x$.doi.org/10.2307/1352458.)

Rebich, R.A., Houston, N.A., Mize, S.V., Pearson, D.K., Ging, P.B., and Evan Hornig, C., 2011, Sources and delivery of nutrients to the northwestern Gulf of Mexico from streams in the south-central United States: Journal of the American Water Resources Association, v. 47, no. 5, p. 1061-1086. (Also available at $h t t p: / / d x$. doi.org/10.1111/j.17521688.2011.00583.x.)

Robertson, D.M., Schwarz, G.E., Saad, D.A., and Alexander, R.B., 2009, Incorporating uncertainty into the ranking of SPARROW model nutrient yields from Mississippi/Atchafalaya River Basin watersheds: Journal of the American Water Resources Association, v. 45, no. 2, p. 534-549. (Also available at $h t t p: / / d x . d o i . o r g / 10.1111 / j .1752-$ 1688.2009.00310.x.)

Seitzinger, S., Harrison, J.A., Böhlke, J.K., Bouwman, A.F., Lowrance, R., Peterson, B., Tobias, C., and others, 2006, Denitrification across landscapes and waterscapes-A synthesis: Ecological Applications, v. 16, no. 6, p. 2064-2090.

U.S. Geological Survey, variously dated, National field manual for the collection of water-quality data: U.S. Geological Survey Techniques of Water-Resources Investigations, book 9, chaps. A1-A9. (Also available at http://pubs.water. usgs.gov/twri9A.)

Welch, H., Green, C., and Coupe, R., 2011, The fate and transport of nitrate in shallow groundwater in northwestern Mississippi, USA: Hydrogeology Journal, v. 19, no. 6, p. 1239-1252. (Also available at $h t t p: / / d x . d o i . o r g / 10.1007 /$ s10040-011-0748-8.)

Wetzel, R.G., 2001, Limnology—Lake and river ecosystems ( $3 \mathrm{~d}$ ed.): Academic Press, 1,006 p. 
Appendix 1. Field properties and inorganic data collected as part of the Big Sunflower River nitrogen occurrence and transport study, October 1, 2009-June 30, 2011

The Microsoft Excel spreadsheet containing appendix 1 is available at $h t t p: / / d x . d o i . o r g / 10.3133 /$ sir20145107. 
Manuscript approved June 4, 2014

For more information about this publication, contact:

\section{Director}

Mississippi Water Science Center

308 South Airport Road Road

Jackson, MS 39208

(601) 933-2900

or visit the USGS Mississippi Water Science Center Web site at: http://ms.water.usgs.gov

Prepared by the Raleigh Publishing Service Center 

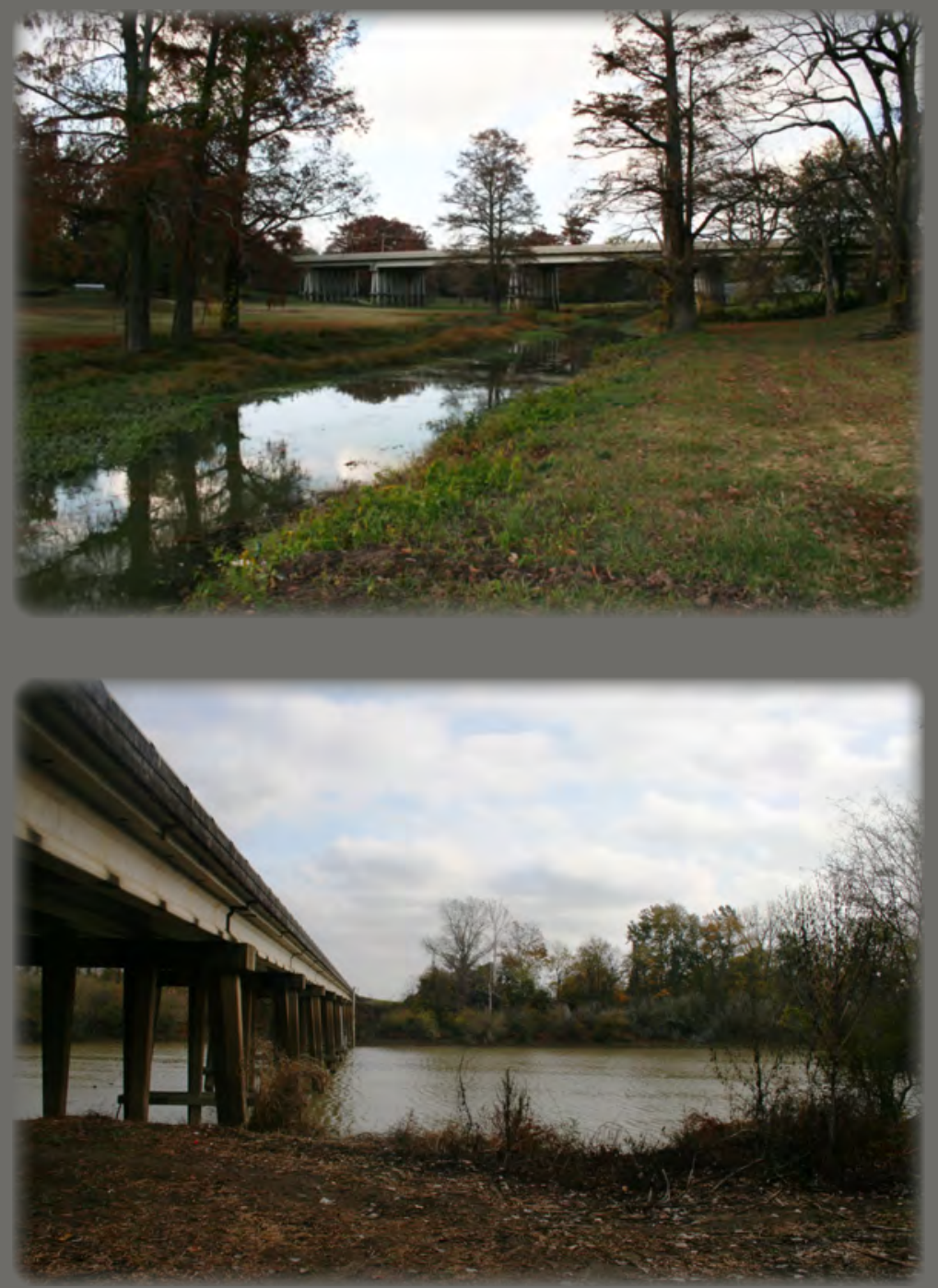